\title{
CONTRIBUTION TO THE KNOWLEDGE ON THE FLORA OF MT GOLESH, CENTRAL KOSOVO
}

\author{
Elez Krasniqi, Naim Berisha*, Fadil Millaku \& Ferat Rexhepi ${ }^{\dagger}$
}

Department of Biology, Faculty of Natural Sciences and Mathematics, University of Prishtina 'Hasan Prishtina', Republic of Kosovo

Krasniqi, E., Berisha, N., Millaku, F. \& Rexhepi, F.: Contribution to the knowledge on the flora of Mt Golesh, central Kosovo. Nat. Croat., Vol. 28, No. 2., 423-440, Zagreb, 2019.

This paper presents the results of a detailed floristic study conducted during three consecutive years (2015-2017) in the central part of Kosovo, in the mountain of Golesh. The studied mountainous area is unique by reason of its ecosystems and has a high degree of diversity of regional flora. Because of its specific harsh environment the area as a whole contains a considerable amount of endemic and rare plant taxa. Therefore, the flora of different habitats of the area has been properly investigated and must be adequately protected. All recorded taxa in this study correspond to the collected voucher specimens. Conservation statuses for endangered taxa were also proposed based on the relevant literature data. As a result of the research, 62 families, 199 genera, and 295 taxa (species and infraspecific taxa) of vascular plants were recorded, including eight endemic plant taxa and, in total, twelve endangered plant taxa. Growing on Mt Golesh are one critically endangered (Klasea radiata), three endangered (Narcissus poeticus subsp. radiiflorus, Haplophyllum boisserianum and Daphne cneorum), two vulnerable (Centaurea albertii and Galatella albanica), two near threatened (Paramoltkia doerfleri and Potentilla visianii) and four least concern plant taxa (Halacsya sendtneri, Linum flavum, Forsythia europaea and Polygala doerfleri), indicating that this area has a high conservation value and the necessity for research.

Key words: conservation, endemism, serpentine flora, plant systematics

Krasniqi, E., Berisha, N., Millaku, F. \& Rexhepi, F.: Prinos poznavanju flore planine Golesh, središnje Kosovo. Nat. Croat., Vol. 28, No. 2., 423-440, Zagreb, 2019.

Rad predstavlja rezultate detaljnog florističkog istraživanja provedenog tijekom tri uzastopne godine (2015-2017) na planini Golesh u središnjem dijelu Kosova. Proučavano planinsko područje je jedinstveno zbog svog ekosustava i i posjeduje veliki stupanj raznolikosti regionalne flore. Zbog oštrih uvjeta okoliša na tom području raste značajan broj endemskih i rijetkih vrsta. Stoga je flora različitih staništa tog područja dobro istražena i mora biti adekvatno zaštićena. Sve zabilježene svojte ovog rada imaju i dokaz u prikupljenim primjercima. Za sve ugrožene svojte na temelju relevantnih literaturnih podataka predlaže se zaštita. Kao rezultat istraživanja zabilježene su 62 porodice, 199 rodova i 295 svojti (vrste i podvrste) vaskularnih biljaka, uključujući osam endemskih i 12 ugroženih svojti. Na planini Golesh raste jedna kritično ugrožena (Klasea radiata), tri ugrožene (Narcissus poeticus subsp. radiiflorus, Haplophyllum boisserianum i Daphne cneorum), dvije osjetljive (Centaurea albertii i Galatella albanica), tdvije skoro ugrožene (Paramoltkia doerfleri i Potentilla visianii) i četiri najmanje zabrinjavajuće svojte (Halacsya sendtneri, Linum flavum, Forsythia europaea i Polygala doerfleri), što pokazuje vrijednost zaštite ovog područja i potrebu njegovog istraživanja.

Ključne riječi: zaštita, endemizam, serpentinska flora, biljna sistematika

\section{INTRODUCTION}

The mountain of Golesh (with a surface area of $22.2 \mathrm{~km}^{2}$ ) belongs to the central mountain chain of Carraleva Mountains in Kosovo (MARKović, 1990) and its highest peak rises $1019 \mathrm{~m}$ above sea level (a.s.l). It is the highest mountain system in the central part of Kosovo (ÇAvolLI, 1997). Most of this mountain area (70\%)

\footnotetext{
* corresponding author: naim.berisha@uni-pr.edu
} 
is located at altitudes from 600 to $980 \mathrm{~m}$ a.s.l. - while the upper part reaches the altitude of more than $980 \mathrm{~m}$ a.s.l. Golesh is known as a massif predominantly made out of harzburgite rock (which consists mainly of two minerals: olivine and low calcium peroxine) and a high percentage of ultramafic (serpentinite) bedrock (SAHITI, 2010; LABUS, 1973). This composition represents a challenging environment in chemical, physical and biotic terms for plants to grow and develop in drought, the presence of heavy metals and limited sources of basic nutrients (Herath et al., 2014; Berisha et al., 2014; ReXhepi et al., 2012; KaZakou et al., 2008; Millaku et al., 2008; Kruckeberg, 2006; Krasniqi \& Millaku, 2007). From the pedological aspect, the surveyed area is made of loamy deluvium, brownized red soil on compact limestone, reddish-brown loamy soil on reddish sediments and moderately deep brown soil on metamorphic rocks (PAvićević et al., 1974).

In climatic terms, the studied site is characterized by harsh cold winters and dry and hot summers - with average annual temperature of $10^{\circ} \mathrm{C}$ (Çavolli, 1997). Warmest months are July and August with the average temperature reaching $21^{\circ} \mathrm{C}$, while the coldest month is January with an average temperature of $-1.5^{\circ} \mathrm{C}$, making it a typical continental climate (ANon., 2018).

For Mt Mt Golesh 144 taxa of vascular plants were reported (KRASNiQI et al., 2015). Although RexhepI $(1979,1985)$ recorded c. 139 plant taxa in the Mt Golesh area, detailed floristic research as well as research on endemics is still in progress (Millaku et al., 2017) and new records for the distribution of plant taxa were made during our taxonomic revision of the given studied area.

Still, not a single study has ever been published concerning the floristic diversity of Mt Golesh, offering any plant list. The whole mountain stretches $5.5 \mathrm{~km}$ from south to north and $5.4 \mathrm{~km}$ from its western point to the eastern side along the municipalities of Fushë-Kosova, Drenas and Lipjan.

The most vital zone from the biodiversity point of view is the upper part of the mountain (around the antenna - a triangle between points: 9, 11, 14 and 24 from Tab. 1), where the habitats of endangered plant taxa are located. In this study, we have made efforts to review the biodiversity situation by listing all the sampled plant taxa. We aimed to a) compile a detailed list of all present taxa; $\mathbf{b}$ ) review the threat status of all rare and endangered plant taxa present in this mountain; and c) provide accurate data concerning their overall distribution across the mountain. An accurate identification of plant taxa was based on the collected herbarium specimens, which were used as unique evidence and crucial reference material for the regional distribution. To achieve our objective of reviewing the conservation status of the endemic and endangered taxa present, we relied on the data provided by the Red Book of Vascular Flora of the Republic of Kosovo (Millaku (ed.), 2013).

\section{MATERIAL AND METHODS}

We conducted our field surveys at 50 sites, starting from April to September in three consecutive years 2015-2017 (Tab. 1). A total of approximately 150 sampling sites were visited. Sites were selected randomly, ensuring that no particular portion of the sampling frame was either favoured or overlooked. In order for us to cover 
Tab. 1. Delineation of collecting sites for Golesh mountain area.

\begin{tabular}{|c|c|c|c|c|c|}
\hline No. & Date & Coordinates & Altitude & Exposition & Habitat type \\
\hline 1 & 21.04 .2015 & $42^{\circ} 35.610 \mathrm{~N} ; 020^{\circ} 59.620 \mathrm{E} ;$ & $648 \mathrm{~m}$ & NE & Forest \\
\hline 2 & 10.05 .2015 & $42^{\circ} 34.476 \mathrm{~N} ; 020^{\circ} 58.942 \mathrm{E}$ & $958 \mathrm{~m}$ & NW & Grassland \\
\hline 3 & 15.05.2015 & $42934.226 \mathrm{~N} ; 020959.395 \mathrm{E}$; & $896 \mathrm{~m}$ & NE & Shrubs \\
\hline 4 & 30.05 .2015 & $42^{\circ} 33.860 \mathrm{~N} ; 020^{\circ} 58.647 \mathrm{E}$; & $971 \mathrm{~m}$ & SE & Grassland \\
\hline 5 & 10.06 .2015 & $42^{\circ} 32.993 \mathrm{~N} ; 020^{\circ} 58.835 \mathrm{E}$ & $781 \mathrm{~m}$ & W & Shrubs and forest \\
\hline 6 & 10.06 .2015 & $42^{\circ} 34.355 \mathrm{~N} ; 020^{\circ} 58.450 \mathrm{E}$ & $902 \mathrm{~m}$ & $\mathrm{~N}$ & Grassland \\
\hline 7 & 20.06 .2015 & $42934.500 \mathrm{~N} ; 020^{\circ} 58.879 \mathrm{E}$; & $854 \mathrm{~m}$ & NW & Grassland \\
\hline 8 & 20.06 .2015 & $42^{\circ} 35.229 \mathrm{~N} ; 020^{\circ} 58.645 \mathrm{E} ;$ & $737 \mathrm{~m}$ & NE & Forest \\
\hline 9 & 11.07 .2015 & $42^{\circ} 34.085 \mathrm{~N} ; 020^{\circ} 59.581 \mathrm{E}$ & $957 \mathrm{~m}$ & $E$ & Grassland \\
\hline 10 & 24.07 .2015 & $42^{\circ} 34.406 \mathrm{~N} ; 020^{\circ} 59.155 \mathrm{E}$ & $885 \mathrm{~m}$ & NE & Shrubs and forest \\
\hline 11 & 24.07 .2015 & $42^{\circ} 34.520 \mathrm{~N} ; 020^{\circ} 58.375 \mathrm{E} ;$ & $990 \mathrm{~m}$ & NW & Grassland \\
\hline 12 & 29.07 .2015 & $42^{\circ} 32.224 \mathrm{~N} ; 020^{\circ} 58.381 \mathrm{E} ;$ & $698 \mathrm{~m}$ & SW & Grassland \\
\hline 13 & 02.08 .2015 & $42^{\circ} 33.048 \mathrm{~N} ; 020^{\circ} 58.157 \mathrm{E} ;$ & $744 \mathrm{~m}$ & $\mathrm{~S}$ & Forest \\
\hline 14 & 02.08 .2015 & $42^{\circ} 34.218 \mathrm{~N} ; 020^{\circ} 58.020 \mathrm{E}$ & $995 \mathrm{~m}$ & SW & Grassland \\
\hline 15 & 15.08 .2015 & $42^{\circ} 34.138 \mathrm{~N} ; 020^{\circ} 59.768 \mathrm{E}$; & $983 \mathrm{~m}$ & E & Shrubs \\
\hline 16 & 02.09 .2015 & $42^{\circ} 34.383 \mathrm{~N} ; 020^{\circ} 57.356 \mathrm{E} ;$ & $589 \mathrm{~m}$ & $\mathrm{~W}$ & Grassland \\
\hline 17 & 19.04 .2016 & $42^{\circ} 34.561 \mathrm{~N} ; 020^{\circ} 58.352 \mathrm{E}$ & $921 \mathrm{~m}$ & NW & Grassland \\
\hline 18 & 09.05 .2016 & $42^{\circ} 34.485 \mathrm{~N} ; 020^{\circ} 59.752 \mathrm{E}$ & $781 \mathrm{~m}$ & $\mathrm{~N}$ & Forest \\
\hline 19 & 15.05 .2016 & $42934.749 \mathrm{~N} ; 020^{\circ} 59.025 \mathrm{E}$; & $792 \mathrm{~m}$ & W & Shrubs and forest \\
\hline 20 & 22.05 .2016 & $42^{\circ} 34.546 \mathrm{~N} ; 020^{\circ} 58.024 \mathrm{E} ;$ & $919 \mathrm{~m}$ & $\mathrm{~W}$ & Grassland \\
\hline 21 & 03.06 .2016 & $42^{\circ} 34.342 \mathrm{~N} ; 020^{\circ} 59.873 \mathrm{E}$ & $779 \mathrm{~m}$ & NE & Grassland \\
\hline 22 & 03.06 .2016 & $42^{\circ} 33.796 \mathrm{~N} ; 021^{\circ} 00.017 \mathrm{E}$ & $762 \mathrm{~m}$ & $E$ & Grassland \\
\hline 23 & 15.06 .2016 & $42^{\circ} 34.638 \mathrm{~N} ; 021^{\circ} 57.875 \mathrm{E}$; & $719 \mathrm{~m}$ & SE & Shrubs \\
\hline 24 & 15.06 .2016 & $42^{\circ} 34.131 \mathrm{~N} ; 020^{\circ} 58.906 \mathrm{E} ;$ & $967 \mathrm{~m}$ & NW & Grassland \\
\hline 25 & 05.07 .2016 & $42^{\circ} 34.356 \mathrm{~N} ; 020^{\circ} 58.650 \mathrm{E}$ & $928 \mathrm{~m}$ & $\mathrm{~N}$ & Shrubs \\
\hline 26 & 12.07 .2016 & $42^{\circ} 33.648 \mathrm{~N} ; 020^{\circ} 59.739 \mathrm{E}$ & $736 \mathrm{~m}$ & S & Grassland \\
\hline 27 & 12.07 .2016 & $42^{\circ} 33.906 \mathrm{~N} ; 020^{\circ} 58.381 \mathrm{E} ;$ & $842 \mathrm{~m}$ & $\mathrm{~S}$ & Grassland \\
\hline 28 & 24.07 .2016 & $42^{\circ} 34.643 \mathrm{~N} ; 020^{\circ} 58.757 \mathrm{E}$ & $785 \mathrm{~m}$ & $\mathrm{~W}$ & Forest \\
\hline 29 & 03.08 .2016 & $42^{\circ} 33.368 \mathrm{~N} ; 020^{\circ} 59.187 \mathrm{E} ;$ & $879 \mathrm{~m}$ & SW & Grassland \\
\hline 30 & 03.08 .2016 & $42^{\circ} 35.281 \mathrm{~N} ; 020^{\circ} 58.320 \mathrm{E}$ & $705 \mathrm{~m}$ & $\mathrm{~W}$ & Forest \\
\hline 31 & 18.08 .2016 & $42^{\circ} 33.270 \mathrm{~N} ; 020^{\circ} 59.484 \mathrm{E}$ & $774 \mathrm{~m}$ & NE & Grassland \\
\hline 32 & 02.09 .2016 & $42^{\circ} 34.324 \mathrm{~N} ; 020^{\circ} 57.426 \mathrm{E} ;$ & $802 \mathrm{~m}$ & $\mathrm{~N}$ & Grassland \\
\hline 33 & 15.09 .2016 & $42^{\circ} 34.672 \mathrm{~N} ; 020^{\circ} 59.566 \mathrm{E}$ & $739 \mathrm{~m}$ & NW & Shrubs and forest \\
\hline 34 & 20.04 .2017 & $42^{\circ} 35.330 \mathrm{~N} ; 020^{\circ} 58.459 \mathrm{E} ;$ & $706 \mathrm{~m}$ & $\mathrm{~N}$ & Forest \\
\hline 35 & 11.05 .2017 & $42^{\circ} 34.256 \mathrm{~N} ; 020^{\circ} 58.553 \mathrm{E}$; & $999 \mathrm{~m}$ & NW & Grassland \\
\hline 36 & 11.05 .2017 & $42^{\circ} 33.836 \mathrm{~N} ; 020^{\circ} 59.307 \mathrm{E}$; & $871 \mathrm{~m}$ & SW & Grassland \\
\hline 37 & 25.05 .2017 & $42^{\circ} 34.694 \mathrm{~N} ; 020^{\circ 57.899} \mathrm{E} ;$ & $720 \mathrm{~m}$ & $\mathrm{~W}$ & Shrubs and forest \\
\hline 38 & 30.05 .2017 & $42^{\circ} 33.968 \mathrm{~N} ; 020^{\circ} 58.044 \mathrm{E}$ & $841 \mathrm{~m}$ & SE & Grassland \\
\hline 39 & 12.06 .2017 & 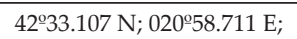 & $750 \mathrm{~m}$ & $\mathrm{~S}$ & Shrubs \\
\hline 40 & 12.06 .2017 & $42 \div 32.805 \mathrm{~N} ; 020^{\circ} 59.393 \mathrm{E} ;$ & $762 \mathrm{~m}$ & E & Grassland \\
\hline 41 & 22.06 .2017 & $42^{\circ} 33.304 \mathrm{~N} ; 020^{\circ} 59.215 \mathrm{E}$ & $889 \mathrm{~m}$ & $E$ & Grassland \\
\hline 42 & 30.06 .2017 & $42^{\circ} 33.361 \mathrm{~N} ; 020^{\circ} 59.028 \mathrm{E}$ & $811 \mathrm{~m}$ & $\mathrm{~W}$ & Grassland \\
\hline 43 & 06.07 .2017 & $42^{\circ} 35.286 \mathrm{~N} ; 020^{\circ} 59.903 \mathrm{E}$; & $666 \mathrm{~m}$ & $\mathrm{NE}$ & Forest \\
\hline 44 & 06.07 .2017 & $42^{\circ} 33.780 \mathrm{~N} ; 021^{\circ} 00.060 \mathrm{E} ;$ & $709 \mathrm{~m}$ & SE & Grassland \\
\hline 45 & 20.07.2017 & $42^{\circ} 34.174 \mathrm{~N} ; 020^{\circ} 57.233 \mathrm{E} ;$ & $753 \mathrm{~m}$ & SW & Grassland \\
\hline 46 & 20.07 .2017 & $42^{\circ} 34.016 \mathrm{~N} ; 020^{\circ} 58.776 \mathrm{E}$ & $941 \mathrm{~m}$ & $\mathrm{~S}$ & Grassland \\
\hline 47 & 26.07 .2017 & $42^{\circ} 34.874 \mathrm{~N} ; 020^{\circ} 56.626 \mathrm{E}$ & $680 \mathrm{~m}$ & $\mathrm{~W}$ & Forest \\
\hline 48 & 15.08 .2017 & $42^{\circ} 34.255 \mathrm{~N} ; 020^{\circ} 59.089 \mathrm{E}$ & $970 \mathrm{~m}$ & NW & Grassland \\
\hline 49 & 01.09 .2017 & $42^{\circ} 34.859 \mathrm{~N} ; 020^{\circ} 59.166 \mathrm{E} ;$ & $780 \mathrm{~m}$ & NW & Shrubs \\
\hline 50 & 17.09 .2017 & $42^{\circ} 33.645 \mathrm{~N} ; 020^{\circ} 58.583 \mathrm{E} ;$ & $825 \mathrm{~m}$ & SE & Grassland \\
\hline
\end{tabular}


all different types of habitats at different elevations and expositions, we sampled plots from forests, shrubs as well as grasslands (starting from $648 \mathrm{~m}$ a.s.1. to 999 $\mathrm{m}$ a.s.l.). Life forms as well as their chorological spectrum follow Pignatti (1982), Dimopoulos et al. (2013) and Raunkiaer (1934). Plots as shown in Tab. 1 in many cases included several nearby localities within the given site.

The plant species nomenclature followed the Euro Med Checklist (Euro+Med, 2006). All the collected herbarium materials were identified based on the Flora Europaea (Tutin et al., 1964 - 1980), Flora of Albania (PAPARisto et al., 1988; Qosja et al., 1992-1996; VANGJELi et al., 2000), Flora of Serbia (Josifović (ed.), 1970-1977; Stevanović (ed.), 2012; SARić \& Diklić (eds.), 1986), Flora of Bulgaria (Jordanov et al., 1963-1979; VelćEv et al., 1982), Flowers of Greece and the Balkans (Polunin, 1980) and Baumführer Europa (SpoHN, 2011). Collected plants were processed into voucher specimens and deposited in the herbarium of the Faculty of Natural Sciences and Mathematics, University of Prishtina.

\section{RESULTS AND DISCUSSION}

In this study we determined the vascular plant diversity of Mt Golesh. The collected plants belong to 62 families, 199 genera and 295 taxa (species and infraspecific units) - (App. 1). Families with the highest number of taxa were Asteraceae (34 taxa), Fabaceae (25 taxa), Rosaceae (21 taxa), Poaceae and Caryophyllaceae (each 18 taxa).

Within the investigated region we recorded eight endemic taxa, out of which six are Balkan endemics (Halacsya sendtneri (Boiss.) Dörfl., Paramoltkia doerfleri (Wettst.) Greuter \& Burdet, Linum flavum L., Forsythia europaea Degen \& Bald., Polygala doerfleri Hayek, Potentilla visianii Pančić, Haplophyllum boisserianum Vis. et Pančić and Daphne cneorum L.) and two are stenoendemic taxa for Kosovo (Centaurea albertii Rexhepi and Galatella albanica Degen). We also recorded and evaluated 12 endangered taxa. (App. 1, Tab. 2, App. 2 \& Fig. 1).

Tab. 2. List of endemic and endangered plant species recorded in the studied area of Golesh.

\begin{tabular}{|c|l|l|l|}
\hline No & Family name & Scientific name & Status note \\
\hline 1. & Amaryllidaceae & Narcissus poeticus subsp. radiiflorus (Salisb.) Baker. & Endangered \\
\hline 2. & Asteraceae & Centaurea albertii Rexhepi & Vulnerable Stenoendemic \\
\hline 3. & Asteraceae & Galatella albanica Degen & Vulnerable Stenoendemic \\
\hline 4. & Asteraceae & Klasea radiata (Waldst. \& Kit.) Á. Lö. \& D. Lö. & $\begin{array}{l}\text { Critically Endangered (New } \\
\text { locality) }\end{array}$ \\
\hline 5. & Boraginaceae & Halacsya sendtneri (Boiss.) Doerfl. & Least Concern Endemic \\
\hline 6. & Boraginaceae & Paramoltkia doerfleri (Wettst.) Gre. \& Burd. & Near Threatened Endemic \\
\hline 7. & Linaceae & Linum flavum L. & Least Concern \\
\hline 8. & Oleaceae & Forsythia europaea Degen \& Bald. & Least Concern Endemic \\
\hline 9. & Polygalaceae & Polygala doerfleri Hayek & Least Concern Endemic \\
\hline 10. & Rosaceae & Potentilla visianii Pančić & Near Threatened Endemic \\
\hline 11. & Rutaceae & Haplophyllum boisserianum Vis. et Panc. & Endangered Endemic \\
\hline 12. & Thymelaceae & Daphne cneorum L. & Endangered \\
\hline
\end{tabular}



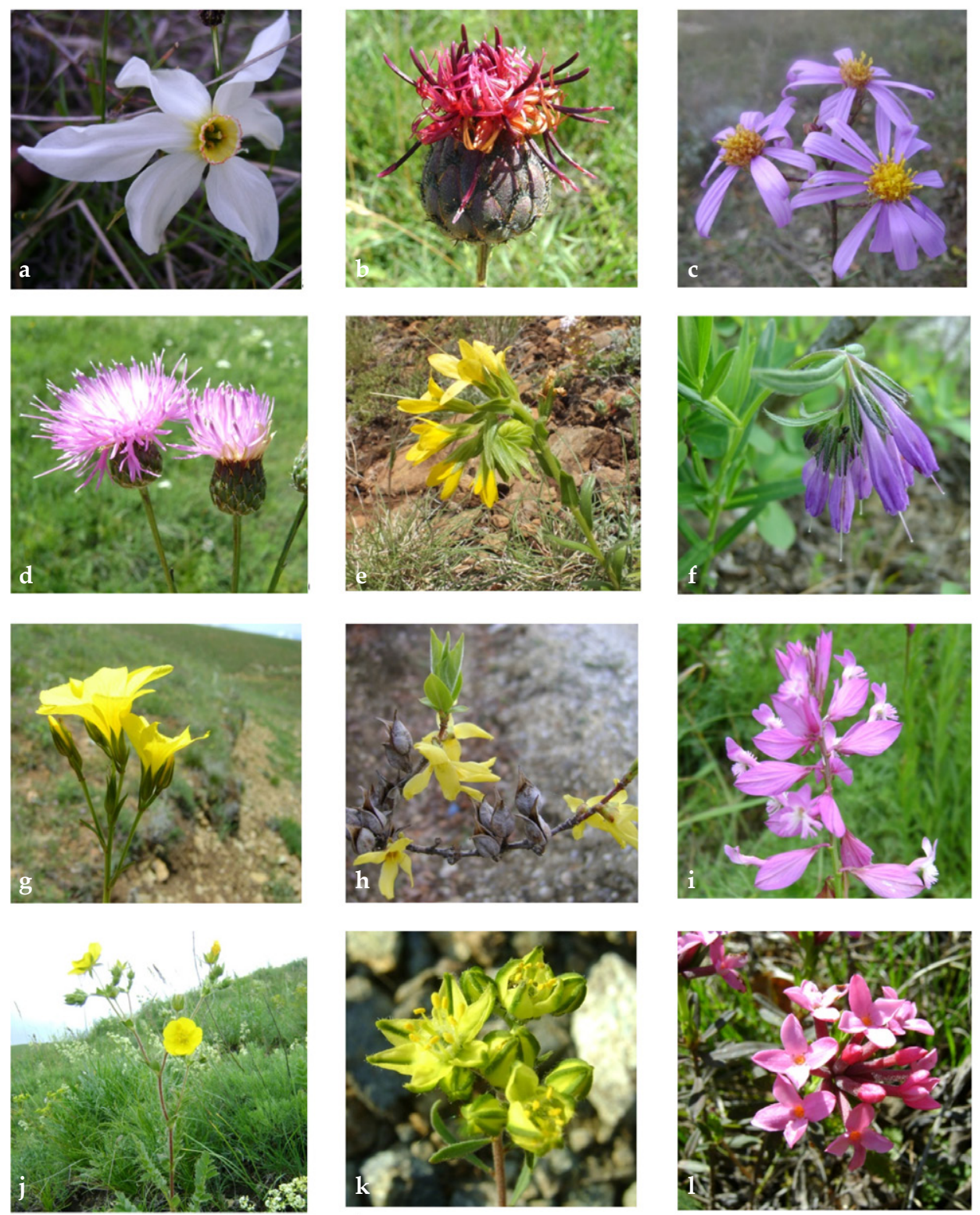

Fig. 1. a) Narcissus poeticus subsp. radiiflorus (Salisb.) Baker., b) Centaurea albertii Rexhepi, c) Galatella albanica Degen, d) Klasea radiata (Waldst. \& Kit.) Á. Löve \& D. Löve, e) Halacsya sendtneri (Boiss.) Doerfl., f) Paramoltkia doerfleri (Wettst.) Greuter \& Burd., g) Linum flavum L., h) Forsythia europaea Degen \& Bald., i) Polygala doerfleri Hayek, j) Potentilla visianii Pančić, k) Haplophyllum boisserianum Vis. et Pančić, 1) Daphne cneorum L. 
On these unique serpentinite-base grassland habitats we registered the presence of the following eight endemic plant taxa (Tab. 2): Centaurea albertii Rexh., Galatella albanica Degen., Halascya sendtneri (Boiss.) Dörfl., Paramoltkia doerfleri (Wettst.) Gre. \& Burd., Forsythia europaea Degen \& Bald., Polygala doerfleri Hayek., Potentilla visianii Pančić and Haplophyllum boisserianum Vis. et Panč.

Additionally, Narcissus poeticus subsp. radiiflorus (Salisb.) Baker., Klasea radiata (Waldst. \& Kit.) Á. Löve \& D. Löve, Linum flavum L. and Daphne cneorum L. are all listed in the Red Data Book of Vascular Flora of Kosovo. They are characterized generally with a wider distribution in the mountains, but their habitats are limited to certain areas and ecological niches. Their populations mostly consisted of very few mature individuals in each habitat and their habitats are considered vulnerable to being negatively affected by the human factor. Our investigation shows that 12 taxa recorded in this survey are under a certain threat category or level (Tab. 3). Among them, Klasea radiata is a Critically Endangered (CR) species, Narcissus poeticus subsp. radiiflorus, Haplophyllum boisserianum and Daphne cneorum are Endangered (E) species, Centaurea albertii and Galatella albanica are Vulnerable (VU) species, Potentilla visianii and Paramoltkia doerfleri are Near Threatened (NT) species, while Linum flavum, Polygala doerfleri, Forsythia europaea and Halascya sendtneri are categorized in the Least Concern (LC) threat category - based on IUCN Red List criteria (Millaku (ed.), 2013).

The flora is dominated by the European floral element (79 taxa), followed by Euro-Asiatic (74), Sub-Mediterranean (34), Balkan (29), Mediterranean (29), Pontic (12) etc. (Fig. 2). The high contribution of European and Euro-Asiatic floristic elements suggests that floristically it was most strongly influenced from the direction of the Alps as well as the Carpathians and Asia Minor (Stevanović, 1996). Anyhow, as observed, it is obvious that various floristic elements meet and overlap in these mountain ranges in the central part of Kosovo.

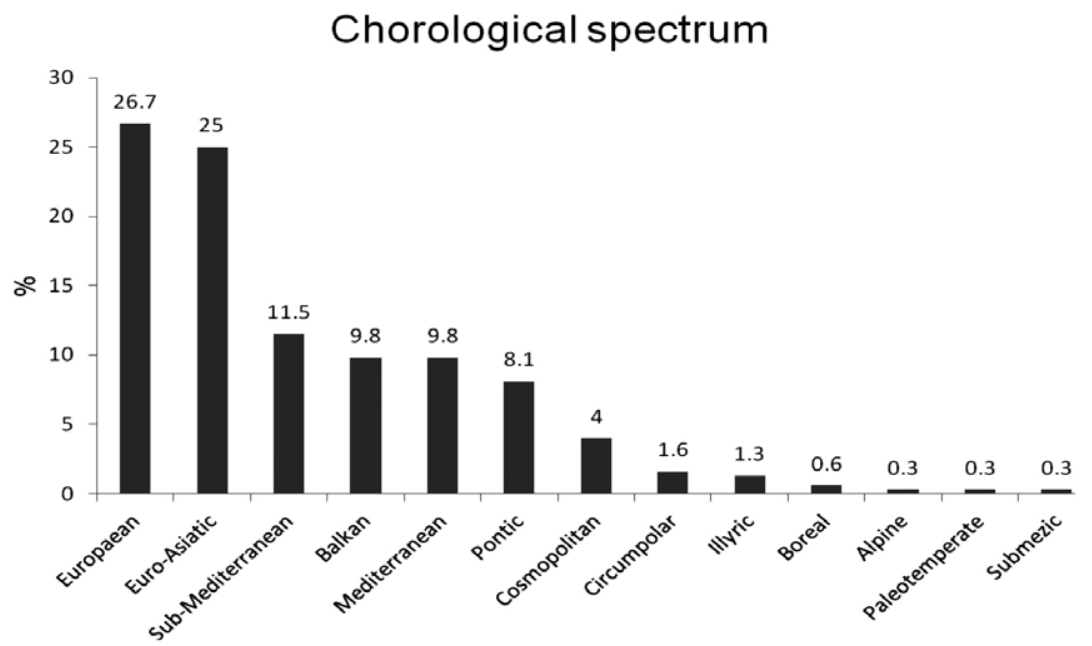

Fig. 2. Chorological spectrum of the total flora from Mt Golesh 
Families with the highest number of taxa (Fig. 3) were Asteraceae (12\%), Fabaceae (9\%), Rosaceae (7\%), Poaceae and Caryophyllaceae (6\% each).

The data presented about endemic and endangered taxa, as well as their conservation status based on literature sources and proven on site with our results, strongly confirm the importance that this mountain has for Kosovo's floristic biodiversity. Altogether eight taxa were endemic $(2.7 \%)$, and 12 were endangered (4\%).

The life-form spectrum indicates the predominance of Hemicryptophytes (153 taxa, 53\%), with a relevant presence of Geophytes (45 taxa, 15\%), Phanerophytes (34 taxa, 12\%) and Therophytes (34 taxa, 12\%) (Fig. 4).

\section{Spectrum of plant families}

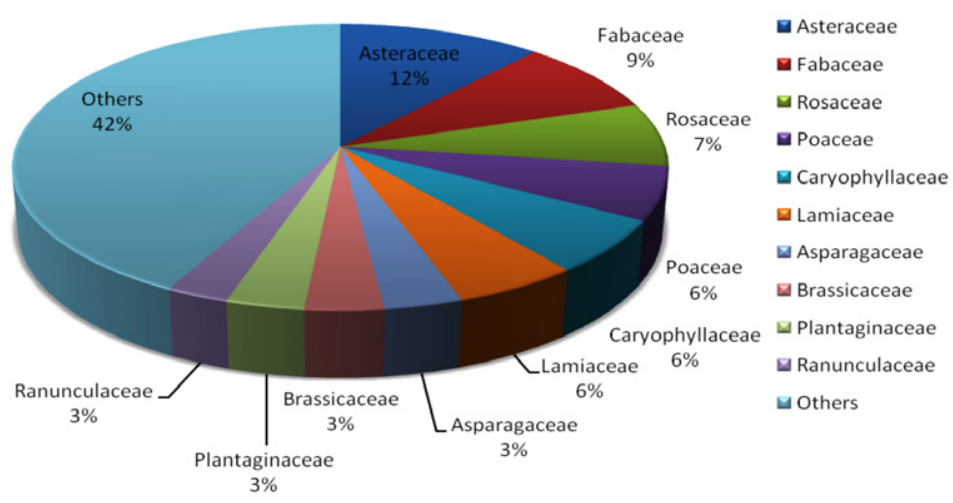

Fig. 3. Spectrum of the most dominant plant families in the studied area of Golesh.

\section{Life form spectrum}

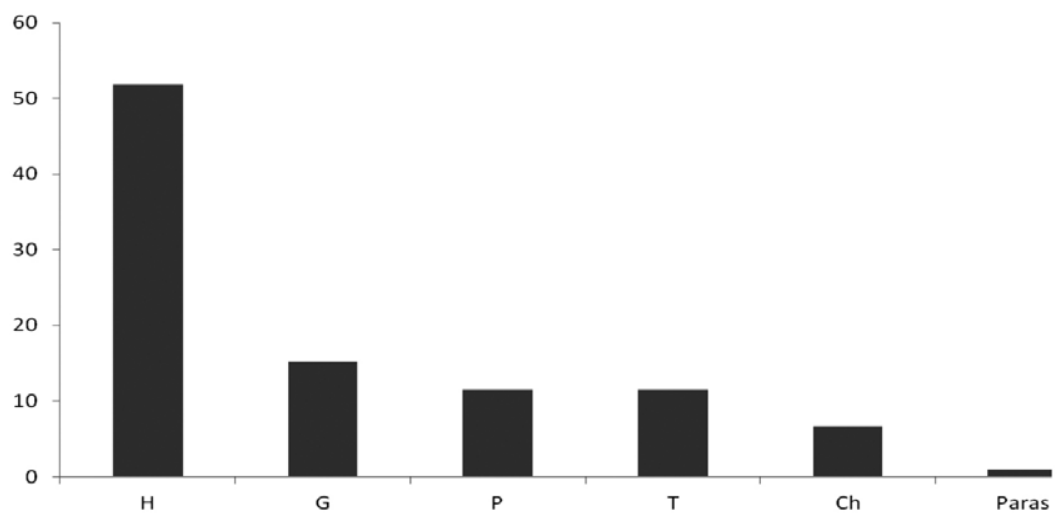

Fig. 4. Life form spectrum of plant taxa recorded on Golesh. 


\section{CONCLUSIONS}

Mt Golesh represents a typical hilly to mountainous landscape of mosaic plant assemblages and diversity, with high presence of serpentinite bedrock of the massif. This detailed floristic documentation of 295 taxa, 199 genera and 62 plant families represents an important contribution towards the knowledge of flora of the Kosovo.

It was noticed that certain endemic taxa are very fragile here and the area is heavily disturbed by humans as well as by grazing animals. At the very top of the mountain there is a military compound and near its border fences (N \& S) we noticed the presence of natural habitats for Centaurea albertii Rexhepi - a stenoendemic plant taxon. We suggest that this area (Tab. 1, area between collections sites no. 24, 35 and 48) should be protected and also we point out the need for increasing the general awareness of local people about the importance of conserving this environment.

From the floristic point of view, Golesh is particularly important due to the presence of eight endemic taxa, twelve endangered taxa and the outstanding diversity of its flora. Additionally, natural habitats of Forsythia europaea here represent the northernmost natural distributional limit of the endemic taxon.

The habitat of the stenoendemic Galatella albanica is characterized by a very fragile population consisting of very few mature individuals that are also naturally isolated. It was recorded on the serpentinite grasslands of the eastern slope - and taking into the account also the information of the taxa overall distribution and its threat situation in Kosovo, it should remain protected by law (already listed in the Red Book of Vascular Flora of the Republic of Kosovo - VU).

Haplophyllum boisserianum is an endangered plant taxon in Kosovo. Because of our detailed floristic research into this area we recorded a new locality of its natural distribution. for $H$. boisserianum was growing on dry serpentine grasslands of the western slopes of Mt Golesh.

The results of this work will considerably support the conservation activities of the flora as well as natural habitats in Kosovo and additionally will update the floristic database concerning the composition and general distribution of plant taxa.

\section{ACKNOWLEDGMENTS}

The authors gratefully thank botany students Ramiz Kozhani, Gazmend Hoti, Shpresa Gashi, Mimozë Paçarizi, Sahit Kastrati and Gëzim Gjoshi for their supports in performing this survey in the field. The authors are grateful to Hazbije Krasniqi for the technical assistance in finalizing the work. We would like to thank the two anonymous reviewers for their careful reading of our manuscript and many insightful comments and suggestions. 


\section{REFERENCES}

AnONYmous, 2018: Hydrometeorological yearbook of Kosovo 2015-2016. Hydrometeorological Institute of Kosovo. MESP, Prishtina.

Berisha, N., Millaku, F., Krasniqi, E. \& Gashi, B., 2014: Rare and endangered geophyte plant species in serpentine of Kosovo. Ecologia Balkanica 6(2), 67-74.

Çavolli, R., 1997: Regional geography of Kosovo. ETMK. Prishtine (in Albanian).

Euro+Med, 2006-: Euro+Med PlantBase - the information resource for Euro-Mediterranean plant diversity. Published on the Internet http://ww2.bgbm.org/EuroPlusMed/ [accessed: 02.10.2017].

Herath, I. P., Kumarathilaka, A., Navaratne, N., Rajakaruna, M., Vithanage, 2014: Immobilization and phytotoxicity reduction of heavy metals in serpentine soil using biochar. Journal of Soils and Sediments 15(1), 126-138. DOI 10.1007/s11368-014-0967-4

Jäger, E., Müller, F., Ritz, Ch. M., Welk, E. \& Wesche, K., 2013: Exkursionsflora von Deutschland, Gefäßpflanzen: Atlasband. 12 Auflage. Springer spectrum. Berlin.

Jordanov, D., Kitanov, B. \& Valjev, S., 1963-1964: Flora of RP Bulgaria. Vols. 1, 2. Bulgarian Academy of Sciences and Arts. Sofia.

Jordanov, D. \& Kožuharov, S., 1970: Flora of RP Bulgaria. Vol. 4. Bulgarian Academy of Sciences and Arts. Sofia.

Jordanov, D. \& Kuzmanov, B., 1966: Flora of RP Bulgaria. Vol. 3. Bulgarian Academy of Sciences and Arts. Sofia.

Jordanov, D. \& Kuzmanov, B., 1979: Flora of RP Bulgaria. Vol. 7. Bulgarian Academy of Sciences and Arts, Sofia.

Josifović, M. (ed.), 1970-1977: Flora SR Srbije, Vols 1-9. Srpska akademija nauka i umetnosti, Beograd.

Kazakou, E., Dimitrakopoulos, P. G., Baker, A. J. M., Reeves, R. D. \& Troumbis, A. Y., 2008 : Hypotheses, mechanisms and trade-offs of tolerance and adaptation to serpentine soils: from species to ecosystem level. Biological Reviews 83, 495-508. doi:10.1111/j.1469-185X.2008.00051.x

Krasniqi, E. \& Millaku, F., 2007: The association Hyperico-Euphorbietum glabriflorae Rexhepi 1978 in the serpentine terrains of Drenica Mountain. Hacquetia. 6(2), 183-193.

Krasniqi, E., Millaku, F., Gjoshi, G., Berisha, N. \& Rexhepi, F., 2015: Floristic composition on the forests and shrubs of Golesh Mt. including the surrounding area. SGEM 3(2), 477-482.

Kruckeberg, A. R., 2006: Introduction to California soils and plants: serpentine, vernal pools, and other geobotanical wonders. University of California Press.

Labus, D., 1973: Hydrological characteristics of Golesh mountain. Bulletin of Scientific Papers, FNMS, UP. Prishtina.

Marković, Đ. J., 1990: Enciklopedijski Geografski Leksikon Jugoslavije. 2. Ed.. Svjetlost, Sarajevo.

Millaku, F. (Ed), Rexhepi, F., Krasniqi, E., Pajazitaj, Q., Mala, Xh. \& Berisha, N., 2013: The Red Book of Vascular Flora of the Republic of Kosovo. MEST, Prishtina.

Millaku, F., Heiselmayer, P., Rexhepi, F., Krasniqi, E., Eichberger, Ch. \& Haziri, A., 2008: Endemic, steno-endemic and relict plants in serpentines of Kosova. Sauteria, 16, 149-162.

Millaku, F., Krasniqi, E., Berisha, N. \& Rexhepi, F., 2017: Conservation assessment of the endemic plants from Kosovo. Hacquetia. 16(1), 35-47. DOI: 10.1515/hacq-2016-0024

Paparisto, K., Demiri, M., Mitrushi, I. \& Qosja, XH., 1988: Flora of Albania - Vol. 1. Albanian Academy of Sciences and Arts. Tirana.

Pavićević, N., Grujić, U., Milošević, Lj., Katalina, P. \& Vasić, G., 1974: Pedological map of Kosovo. Beograd (in Serbian).

Pignatti, S., 1982: Flora d'Italia, 1-3. Edagricole, Bologna.

Polunin, O., 1980: Flowers of Greece and the Balkans - a field guide. Oxford University Press. Oxford, United Kingdom.

Qosja, Xh., Paparisto, K., Demiri, M. \& Vangjeli, J., 1992: Flora of Albania - Vol. 2. Albanian Academy of Sciences and Arts, Tirana.

Qosja, Xh., Paparisto, K., Demiri, M., Vangjeli, J., Ruci, B. 1996: Flora of Albania - Vol. 3. Albanian Academy of Sciences and Arts. Tirana.

Raunkiaer, C., 1934: The life-forms of plants and statisticalplant geography. Clarendon Press, Oxford.

Rexhepi, F., 1979: Contribution to the knowledge of serpentinite flora of Kosovo. Bioteknika 9, 75-83, Prishtine (in Albanian). 
REXHEPI, F., 1985: Ways of protecting flora and vegetation in serpentines of Kosovo. Nature of Kosovo 5, 101-119 (in Albanian).

RexhepI, F., 1986: Centaurea albertii Rexhepi sp. nov. new species from genus Centaurea L. Glasn. Prir. Muz. Beogradu 41, 27-36 (in Serbian).

Rexhepi, F., Millaku, F. \& Krasniqi, E., 2012: Forest and shrub ecosystems on the serpentines of the Republic of Kosovo. SGE 4(9), 9-16.

SAHitr, F., 2010: Designed geological models and their application at the origin of Nickel in Gllavica (Master's Thesis). University of Mitrovica (in Albanian).

SARIĆ, M. R. \& Diklić, N. (eds.), 1986: Flora SR Srbije, Vol. 10. Srpska akademija nauka i umetnosti, Beograd.

Spoнn, R. \& Spohn, M., 2011: Kosmos-Baumführer Europa. Franckh Kosmos Verlag. Berlin, Germany.

Stevanović, V., 1996: Analysis of the Central European and Mediterranean orophytic element on the mountains of the W. and Central Balkan Peninsula, with speeial reference to endemics. Bocconea 5, 77-97.

Stevanović, V. (ed.), 2012. Flora Srbije, Vol. 2. Srpska akademija nauka i umetnosti, Beograd.

Tutin, H.G., Heywood, V.H., Burges, N.A., Moore, D.M., Valentine, D.H., Walters, S.M. \& WebB, D.A. (eds.), 1968-1980. Flora Europaea, Vols 2-5. Cambridge University Press. Cambridge.

Vangjeli, J., Ruci, B., Mullaj, A., Papa Risto, K. \& Qosja, XH., 2000: Flora of Albania - Vol. 4. Albanian Academy of Sciences and Arts, Tirana.

Velćev, V, D. \& Kožuharov, S., 1982: Flora of RP Bulgaria. Vol. 8. Bulgarian Academy of Sciences and Arts, Sofia.

Appendix I. Floristic composition of Golesh with distribution \& conservation notes

\begin{tabular}{|c|c|c|c|c|c|}
\hline \multirow[t]{2}{*}{$\ddot{Z}$} & \multirow[t]{2}{*}{ 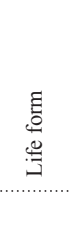 } & \multirow{2}{*}{$\begin{array}{l}\text { Family } \\
\text { Taxon } \\
\text { Aspleniaceae }\end{array}$} & \multirow[t]{2}{*}{ 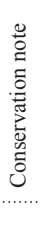 } & \multirow[t]{2}{*}{$\begin{array}{l}\text { Herbarium no. / } \\
\text { (Habitat type \& Expositions on site) }\end{array}$} & \multirow[t]{2}{*}{ 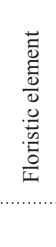 } \\
\hline & & & & & \\
\hline 1. & $\mathrm{H}$ & $\begin{array}{l}\text { Asplenium adiantum-nigrum subsp. } \\
\text { serpentini (Tausch) Heufl. } \\
\text { [ Asplenium cuneifolium Viv.] }\end{array}$ & $\backslash$ & GOL005 / (Forest \& forest clearings) & EUR \\
\hline 2. & $\mathrm{H}$ & $\begin{array}{l}\text { Asplenium ceterach } \mathrm{L} \text {. } \\
\text { [Ceterach officinarum DC.] }\end{array}$ & $\backslash$ & GOL006 / Forest \& shrubs (N, E, W, S) & EUA \\
\hline \multirow[t]{2}{*}{5.} & $\mathrm{Ch}$ & Polypodium vulgare L. & $\backslash$ & GOL073 / (Forest \& forest clearings) & EUA \\
\hline & & Cupressaceae & & & \\
\hline 6. & $\mathrm{P}$ & Juniperus communis L. & 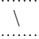 & GOL056 / Forest \& shrubs (N, E, W, S) & CRP \\
\hline \multirow[t]{2}{*}{7.} & $\mathrm{P}$ & Juniperus oxycedrus L. & 1 & GOL057 / Forest \& shrubs (N, E, W, S) & MED \\
\hline & & Araceae & & & \\
\hline \multirow[t]{2}{*}{8.} & $\mathrm{G}$ & Arum maculatum L. & 1 & GOL029 / Forest \& shrubs (N, E, W, S) & EUA \\
\hline & & Colchicaceae & & & \\
\hline 9. & $\mathrm{G}$ & Colchicum autumnale L. & 1 & GOL119 / Grasslands (N, E, W, S) & EUR \\
\hline 14. & G & Convalaria majalis L. & 1 & GOL084 / (Forest \& forest clearings) & SMD \\
\hline 15. & G & Muscari botryoides (L.) Miller. & $\backslash$ & GOL092 / Grasslands (W) & SMD \\
\hline
\end{tabular}




\begin{tabular}{|c|c|c|c|c|c|}
\hline 16. & G & Muscari comosum (L.) Mill. & 1 & $\begin{array}{l}\text { GOL098 / Forest \& forest clearings, rocky } \\
\text { grasslands (E) }\end{array}$ & EUR \\
\hline 17. & G & Muscari racemosum (L.) Lam. et DC. & 1 & $\begin{array}{l}\text { GOL } 111 \text { / Forest \& shrubs, rocky grasslands (N, } \\
\text { E, S) }\end{array}$ & MED \\
\hline 18. & G & Ornithogalum pyramidale $\mathrm{L}$. & 1 & GOL156 / Grasslands (E) & EUR \\
\hline 19. & $\mathrm{G}$ & Ornithogalum umbellatum L. & 1 & GOL157 / Forest \& shrubs (N, E, S, W) & EUR \\
\hline 20. & $\mathrm{G}$ & Polygonatum odoratum (Mill.) Druce & 1 & GOL161 / (Forest \& forest clearings) & EUA \\
\hline 21. & G & $\begin{array}{l}\text { Prospero autumnale (L.) Speta } \\
\text { [Scilla autumnalis L.] }\end{array}$ & 1 & GOL107 / Grasslands (N, E, S, W) & MED \\
\hline \multirow[t]{2}{*}{22.} & G & Scilla bifolia $\mathrm{L}$. & 1 & GOL033 / Forest \& forest clearings & MED \\
\hline & & Orchidaceae & & & \\
\hline 23. & G & $\begin{array}{l}\text { Anacamptis morio (L.) R. M. B. Pr. \& } \\
\text { M.W. Ch. } \\
{[\text { Orchis morio L.] }}\end{array}$ & 1 & GOL231 / Grasslands (N, E, S, W) & MED \\
\hline \multirow[t]{2}{*}{24.} & $\mathrm{G}$ & Platathera bifolia (L.) L. C. M. Richard. & 1 & GOL235 / Forest \& forest clearings & EUA \\
\hline & & Iridaceae & & & \\
\hline 25. & $\mathrm{G}$ & Crocus biflorus Mill. & 1 & GOL222 / Grasslands (N, E, S, W) & MED \\
\hline 26. & G & Crocus chrysanthus Herb & 1 & GOL223 / Grasslands (N, E, S, W) & BLK \\
\hline 27. & G & Iris graminea $\mathrm{L}$. & 1 & GOL224 / Grasslands (N, E) & MED \\
\hline 28. & G & Iris pumila $\mathrm{L}$. & 1 & GOL225 / Grasslands (E,W) & EUR \\
\hline \multirow[t]{2}{*}{29.} & $\mathrm{H}$ & Iris reichenbachii Heuff. & 1 & GOL226 / Grasslands (N, S) & BLK \\
\hline & & Amaryllidaceae & & & \\
\hline 30. & $\mathrm{G}$ & Allium flavum $\mathrm{L}$. & 1 & GOL216 / Grasslands (N, E, S, W) & EUA \\
\hline 31. & G & Allium moschatum L. & 1 & GOL217 / Grasslands (W) & EUR \\
\hline 32. & G & Allium sphaerocephalon $\mathrm{L}$. & 1 & GOL218 / Grasslands (N, E, S, W) & EUA \\
\hline \multirow[t]{2}{*}{33.} & G & $\begin{array}{l}\text { Narcissus poeticus subsp. radiiflorus } \\
\text { (Salisb.) Baker. }\end{array}$ & EN & GOL219/Grasslands (E) & EUR \\
\hline & & Juncaceae & & & \\
\hline 34. & G & Luzula forsteri $(\mathrm{Sm}.) \mathrm{DC}$ & 1 & $\begin{array}{l}\text { GOL } 163 \text { / Forest \& forest clearings. Shrubs. (N, } \\
\text { E, S, W) }\end{array}$ & MED \\
\hline \multirow[t]{2}{*}{35.} & $\mathrm{H}$ & $\begin{array}{l}\text { Luzula multiflora (Ehrh.) Lej. } \\
\text { [L. campestris L. subsp. multiflora } \\
\text { (Reitz.) Buchenau] }\end{array}$ & 1 & GOL164 / Grasslands (N, E, S, W) & $\mathrm{CSM}$ \\
\hline & & Cyperaceae & & & \\
\hline 36. & $\mathrm{H}$ & Carex caryophyllea Latuorr. & 1 & GOL062 / Grasslands (N, E, S, W) & EUA \\
\hline \multirow[t]{2}{*}{37.} & G & $\begin{array}{l}\text { Scirpoides holoschoenus (L.) Soják } \\
{[\text { Scirpus holoschoenus L.] }}\end{array}$ & 1 & GOL063 / Grasslands (N, E, W) & MED \\
\hline & & Poaceae & & & \\
\hline 38. & $\mathrm{~T}$ & Aegilops triuncialis L. & $i$ & GOL180 / Grasslands (N, E, S, W) & EUR \\
\hline 39. & $\mathrm{H}$ & $\begin{array}{l}\text { Agropyron cristatum subsp. pectinatum } \\
\text { (M. Bieb.) Tzvelev }\end{array}$ & 1 & GOL181 / Grasslands (E, S, W) & PAL \\
\hline 40. & $\mathrm{H}$ & $\begin{array}{l}\text { Brachypodium sylvaticum (Hudson) } \\
\text { Beauv }\end{array}$ & 1 & GOL182 / Forest \& shrubs & EUA \\
\hline 41. & $\mathrm{H}$ & Briza media L. & 1 & GOL183 / Grasslands (N, E, S) & EUA \\
\hline 42. & $\mathrm{H}$ & $\begin{array}{l}\text { Bromus erectus Huds. subsp. fibrosus } \\
\text { (Hack.) Stoj. et Stef. }\end{array}$ & 1 & GOL184 / Grasslands (N, E, W) & SMD \\
\hline 43. & $\mathrm{~T}$ & Bromus squarrosus L. & 1 & GOL 185 / Grasslands (N, E, S, W) & MED \\
\hline 44. & $\mathrm{H}$ & Chrysopogon gryllus (L.) Trin. & 1 & GOL186 / Grasslands (N, E, S, W) & MED \\
\hline 45. & G & Cynodon dactylon (L.) Pers. & 1 & GOL 187 / Grasslands (N, E, S, W) & CSM \\
\hline 46. & $\mathrm{H}$ & Dactylis glomerata L. & 1 & GOL188 / Forest clearings. Grasslands. (N, S) & EUA \\
\hline 47. & G & $\begin{array}{l}\text { Elytrigia repens }(\mathrm{L} .) \text { Nevski } \\
\text { [Agropyrum repens }(\mathrm{L} .) \text { Beauv.] }\end{array}$ & 1 & GOL189 / Grasslands (N) & EUA \\
\hline 48. & $\mathrm{H}$ & $\begin{array}{l}\text { Koeleria macrantha (Ledeb.) Schult. } \\
\text { [Koeleria gracilis Pers.] }\end{array}$ & 1 & GOL190 / Grasslands (W) & EUA \\
\hline 49. & $\mathrm{H}$ & Melica ciliata $\mathrm{L}$. & 1 & GOL191 / Grasslands. Forests. Shrubs. (N, E, W) & EUR \\
\hline 50. & G & Melica uniflora Retz. & 1 & GOL192 / Forest \& shrubs. (N, E, S, W) & EUR \\
\hline 51. & $\mathrm{H}$ & Phleum pratense $\mathrm{L}$. & 1 & GOL193 / Grasslands. (N, E, S, W) & EUA \\
\hline 52. & $\mathrm{H}$ & Poa bulbosa $\mathrm{L}$. & 1 & $\begin{array}{l}\text { GOL } 194 \text { / Forest clearings. Grasslands. (N, E, } \\
\text { S, W) }\end{array}$ & EUA \\
\hline 53. & $\mathrm{~T}$ & Schlerochloa dura (L.) Beauv. & 1 & GOL 195 / Grasslands (W) & MED \\
\hline
\end{tabular}




\begin{tabular}{|c|c|c|c|c|c|}
\hline 54. & $\mathrm{H}$ & $\begin{array}{l}\text { Stipa pulcherrima K. Koch. } \\
\text { [S. pennata subsp. mediterranae (Trin. et } \\
\text { Rupr.) Asch. et Graebn.] }\end{array}$ & 1 & GOL196 / Rocky grasslands (N, E, S, W) & EUR \\
\hline \multirow[t]{2}{*}{55.} & $\mathrm{H}$ & $\begin{array}{l}\text { Taeniatherum caput-medusae subsp. } \\
\text { asperum (Simonk.) Melderis } \\
\text { [Hordeum asperum (Simk.) Deg.] }\end{array}$ & 1 & GOL197 / Grasslands (N) & EUA \\
\hline & & Ranunculaceae & & & \\
\hline 56. & $\mathrm{~T}$ & Consolida regalis S. F. Gray. & 1 & GOL064 / Grasslands (W) & EUR \\
\hline 57. & G & $\begin{array}{l}\text { Ficaria verna Huds. } \\
\text { [Ranunculus ficaria } \mathrm{L} .]\end{array}$ & 1 & GOL065 / Forest \& shrubs (N, E, S, W) & EUR \\
\hline 58. & $\mathrm{H}$ & $\begin{array}{l}\text { Helleborus odorus Waldst. \& Kit. ex } \\
\text { Willd. }\end{array}$ & 1 & GOL066 / Forest \& shrubs (N, E, S, W) & SMZ \\
\hline 59. & G & Isopyrum thalictroides $\mathrm{L}$. & 1 & GOL067 / Forest \& shrubs (N, E, S, W) & EUR \\
\hline 60. & $\mathrm{H}$ & Ranunculus millefoliatus Vahl. & 1 & GOL068 / Grasslands (N, E, S, W) & BLK \\
\hline 61. & $\mathrm{G}$ & Ranunculus psilostachys Griseb. & 1 & GOL069 / Forest \& shrubs. (N, E, S, W) & BLK \\
\hline 62. & $\mathrm{H}$ & Thalictrum aquilegifolium L. & 1 & GOL070 / Forest \& shrubs. (N, E, S, W) & EUR \\
\hline \multirow[t]{2}{*}{63.} & $\mathrm{H}$ & Thalictrum minus L. & 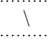 & GOL071 / Grasslands (N) & EUA \\
\hline & & Berberidaceae & & & \\
\hline \multirow[t]{2}{*}{64.} & P & Mahonia aquifolium (Pursh.) Nut. & 1 & GOL009 / Forests. (W, S) & PNT \\
\hline & & Papaveraceae & & & \\
\hline \multirow[t]{2}{*}{65.} & G & Corydalis solida (L.) Claivr. & 1 & GOL061 / Forest \& shrubs. (N, E, S, W) & SMD \\
\hline & & Crassulaceae & & & \\
\hline 66. & $\mathrm{H}$ & Sedum acre L. & 1 & GOL232 / Grasslands (N, S, W) & EUA \\
\hline 67. & $\mathrm{H}$ & Sedum hispanicum L. & 1 & GOL233 / Grasslands (W) & SMD \\
\hline \multirow[t]{2}{*}{68.} & $\mathrm{H}$ & Sedum ochroleucum Chaix & 1 & GOL234 / Grasslands (N, E, S, W) & SMD \\
\hline & & Celastraceae & & & \\
\hline \multirow[t]{2}{*}{69.} & $\mathrm{P}$ & Euonymus verrucosus Scop. & 1 & GOL072 / Forests. Forests \& shrubs. & EUR \\
\hline & & Clusiaceae & & & \\
\hline 70. & $\mathrm{H}$ & Hypericum barbatum Jacq. & 1 & GOL030 / Grasslands (E) & BLK \\
\hline 71. & $\mathrm{H}$ & Hypericum perforatum $\mathrm{L}$. & 1 & GOL031 / Grasslands (N, E, S) & CSM \\
\hline \multirow[t]{2}{*}{72.} & $\mathrm{H}$ & Hypericum rumeliacum Boiss. & 1 & GOL032 / Grasslands (N, E, S, W) & BLK \\
\hline & & Violaceae & & & \\
\hline 73. & $\mathrm{~T}$ & Viola arvensis Murray. & 1 & GOL081 / Grasslands (E, W) & EUR \\
\hline 74. & $\mathrm{H}$ & Viola odorata L. & 1 & GOL082 / Forests. Forests \& shrubs. & SMD \\
\hline \multirow[t]{2}{*}{75.} & $\mathrm{H}$ & Viola riviniana Rchb. & 1 & GOL083 / Forests. Forests \& shrubs. & EUA \\
\hline & & Linaceae & & & \\
\hline 76. & $\mathrm{H}$ & Linum flavum L. & LC & GOL050 / Grasslands (W) & PNT \\
\hline 77. & $\mathrm{H}$ & $\begin{array}{l}\text { Linum perenne } \mathrm{L} . \\
\text { [L. extraaxillare } \mathrm{Kit}]\end{array}$ & 1 & GOL051 / Grasslands (N, E, S, W) & EUR \\
\hline 78. & $\mathrm{H}$ & Linum tenuifolium $\mathrm{L}$. & 1 & GOL052 / Grasslands (E) & EUR \\
\hline \multirow[t]{2}{*}{ 79. } & $\mathrm{H}$ & Linum tauricum Willd. & 1 & GOL053 / Grasslands (N, E, S, W) & EUR \\
\hline & & Euphorbiaceae & & & \\
\hline 80. & $\mathrm{H}$ & Euphorbia amygdaloides L. & 1 & GOL010 / Forests. Forests \& shrubs. & EUR \\
\hline 81. & $\mathrm{H}$ & $\begin{array}{l}\text { Euphorbia barrelieri Savi var. thesala } \\
\text { (Ferm.) K. Maly. }\end{array}$ & 1 & GOL011 / Grasslands (N, E, S, W) & BLK \\
\hline 82. & $\mathrm{H}$ & Euphorbia cyparissias L. & 1 & GOL012 / Forests. Grasslands. (E) & EUA \\
\hline 83. & $\mathrm{H}$ & Euphorbia glabriflora Vis. & 1 & GOL013 / Grasslands (N, E, S, W) & BLK \\
\hline \multirow[t]{2}{*}{84.} & G & Mercurialis ovata Sternb. et Hoppe. & 1 & GOL014 / Forests \& shrubs & EUR \\
\hline & & Fabaceae & & & \\
\hline 85. & $\mathrm{H}$ & Astragalus glycyphyllos L. & 1 & GOL240 / Forests. Forests \& shrubs. & SMD \\
\hline 86. & $\mathrm{H}$ & Astragalus onobrychis L. & 1 & GOL241 / Grasslands (N, E, S, W) & EUR \\
\hline 87. & $\mathrm{H}$ & Colutea arborescens L. & 1 & GOL242 / Forests \& shrubs. & MED \\
\hline 88. & $\mathrm{Ch}$ & $\begin{array}{l}\text { Cytisus hirsutus L. } \\
\text { [Chamaecytisus hirsutus (L.) Link.] }\end{array}$ & 1 & GOL243 / Forests. Grasslands (N, E, S, W) & SMD \\
\hline 89. & $\mathrm{Ch}$ & Dorycnium pentaphyllum Scop. & 1 & GOL244 / Grasslands (N, E, S, W) & SMD \\
\hline 90. & $\mathrm{H}$ & $\begin{array}{l}\text { Securigera elegans (Pančič) Lassen } \\
\text { [Coronilla elegans } \text { Pančič ] }\end{array}$ & 1 & GOL245 / Forests \& shrubs. & BLK \\
\hline
\end{tabular}




\begin{tabular}{|c|c|c|c|c|c|}
\hline 91. & $\mathrm{Ch}$ & $\begin{array}{l}\text { Genista tinctoria L. } \\
\text { [Genista ovata Waldst. et Kit.] }\end{array}$ & 1 & GOL246 / Forests \& shrubs. & EUA \\
\hline 92. & $\mathrm{Ch}$ & Genista pilosa L. & 1 & GOL247 / Grasslands (E,W) & EUR \\
\hline 93. & $\mathrm{Ch}$ & $\begin{array}{l}\text { Genista sagittalis L. } \\
\text { [Chamaespartium saggitale (L.) P. } \\
\text { Gibbs.] }\end{array}$ & 1 & GOL248 / Forests. Grasslands (N, E, W) & EUR \\
\hline 94. & $\mathrm{H}$ & Hippocrepis comosa $\mathrm{L}$. & 1 & GOL249 / Grasslands (S, W) & SMD \\
\hline 95. & $\mathrm{P}(\mathrm{NP})$ & $\begin{array}{l}\text { Hippocrepis emerus (L.) Lassen subsp. } \\
\text { emerus } \\
{[\text { Coronilla emerus L. subsp. emeroides }} \\
\text { (Boiss. et Sprun.) Hayek] }\end{array}$ & 1 & GOL250 / Grasslands (N, E, W) & EUR \\
\hline 96. & $\mathrm{G}(\mathrm{H})$ & Lathyrus niger (L.) Bernh. & 1 & GOL251 / Forests \& shrubs. & PNT \\
\hline 97. & $\mathrm{~T}$ & Lathyrus venetus (Mill.) Wohlf. & 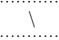 & GOL252 / Forests \& shrubs. & SMD \\
\hline 98. & $\mathrm{P}(\mathrm{NP})$ & Lembotropis nigricans (L.) Griseb. & 1 & GOL 253 / Forests \& shrubs. & SMD \\
\hline 99. & $\mathrm{H}$ & Lotus corniculatus $\mathrm{L}$. & 1 & GOL254 / Grasslands (N, E, S, W) & EUA \\
\hline 100. & $\mathrm{H}$ & Medicago falcata $\mathrm{L}$. & 1 & GOL255 / Grasslands (N) & EUR \\
\hline 101. & $\mathrm{H}$ & Onobrychis alba (Waldst. \& Kit.) Desv. & 1 & GOL256 / Grasslands (E,W) & EUR \\
\hline 102. & $\mathrm{Ch}$ & Ononis spinosa $\mathrm{L}$. & 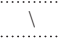 & GOL257 / Grasslands (N,E,S,W) & EUR \\
\hline 103. & $\mathrm{G}$ & Trifolium alpestre $\mathrm{L}$. & 1 & GOL258 / Grasslands (N,E,W) & EUR \\
\hline 104. & $\mathrm{~T}$ & Trifolium arvense $\mathrm{L}$. & ! & GOL259 / Grasslands (N,E,S,W) & EUR \\
\hline 105. & $\mathrm{~T}$ & Trifolium campestre Schreb. & 1 & GOL260 / Grasslands (N,E) & EUR \\
\hline 106. & $\mathrm{H}$ & Trifolium montanum L. & 1 & GOL261 / Forest clearings. Shrubs. & PNT \\
\hline 107. & G & Trifolium pignantii Feuche et Chaub. & 1 & GOL262 / Forests \& shrubs. & BLK \\
\hline 108. & $\mathrm{H}$ & Trifolium pratense L. & 1 & GOL263 / Grasslands (N,E,S) & EUA \\
\hline \multirow[t]{2}{*}{109.} & $\mathrm{H}$ & Vicia cracca $\mathrm{L}$ & 1 & GOL264 / Forests \& shrubs. & EUA \\
\hline & & Polygalaceae & & & \\
\hline \multirow[t]{2}{*}{110.} & $\mathrm{H}$ & Polygala doerfleri Hayek & $\begin{array}{l}\text { LC } \\
\text { End }\end{array}$ & GOL220 / Forests \& shrubs. Grasslands. (N, E) & BLK \\
\hline & & Rosaceae & & & \\
\hline 111. & $\mathrm{P}(\mathrm{NP})$ & Crataegus monogyna L. & 1 & GOL130 / Forests \& shrubs. & EUR \\
\hline 112. & $\mathrm{H}$ & Filipendula vulgaris Moench & 1 & GOL131 / Grasslands (N, E, S, W) & BOR \\
\hline 113. & $\mathrm{H}$ & Fragaria vesca $\mathrm{L}$. & 1 & GOL132 / Forests \& shrubs. Grasslands. (N) & EUR \\
\hline 114. & $\mathrm{H}$ & Geum urbanum L. & 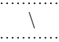 & GOL133 / Forests \& shrubs. & CRP \\
\hline 115. & $\mathrm{P}$ & Malus sylvestris (L.) Mill. & 1 & GOL134 / Forests \& shrubs. & EUR \\
\hline 116. & $\mathrm{H}$ & Potentilla argentea $\mathrm{L}$. & 1 & GOL135 / Grasslands (E,W) & PNT \\
\hline 117. & $\mathrm{H}$ & Potentilla astracanica Jacq. [P. hirta L.] & 1 & GOL136 / Grasslands (N, E, S, W) & PNT \\
\hline 118. & $\mathrm{H}$ & $\begin{array}{l}\text { Potentilla heptaphylla subsp. australis } \\
\text { (Nyman) Gams } \\
\text { [Potentilla australis Krašan] }\end{array}$ & 1 & GOL137 / Grasslands (N, E, S, W) & ILY \\
\hline 119. & $\mathrm{H}$ & Potentilla detommasii Ten. & 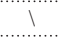 & GOL138 / Forests \& shrubs. & BLK \\
\hline 120. & $\mathrm{H}$ & Potentilla micrantha DC. & 1 & GOL139 / Forests \& shrubs. & SMD \\
\hline 121. & $\mathrm{H}$ & Potentilla visianii Pančić & $\begin{array}{l}\text { NT } \\
\text { End }\end{array}$ & GOL140 / Grasslands (N, E, S, W) & BLK \\
\hline 122. & P(NP) & Prunus spinosa $\mathrm{L}$. & 1 & GOL141 / Forests \& shrubs. & EUA \\
\hline 123. & $\mathrm{P}$ & $\begin{array}{l}\text { Pyrus spinosa Forssk. } \\
\text { [Pyrus amigdaliformis Will.] }\end{array}$ & 1 & GOL142 / Forests \& shrubs. & MED \\
\hline 124. & $P$ & Pyrus elaeagrifolia Pall. & 1 & GOL143 / Forests \& shrubs. & EUA \\
\hline 125. & $\mathrm{P}$ & $\begin{array}{l}\text { Pyrus communis subsp. pyraster (L.) } \\
\text { Ehrh. } \\
\text { [Pyrus pyraster Burgsd.] }\end{array}$ & 1 & GOL144 / Forests \& shrubs. & MED \\
\hline 126. & $\mathrm{P}(\mathrm{NP})$ & Rosa canina L. & 1 & GOL145 / Forests \& shrubs. & EUR \\
\hline 127. & $\mathrm{P}(\mathrm{NP})$ & $\begin{array}{l}\text { Rosa spinosissima } \mathrm{L} . \\
{[\text { Ros a pimpinellifolia } \mathrm{L} .]}\end{array}$ & 1 & GOL146 / Forests \& shrubs. Grasslands. (N, E) & SMD \\
\hline 128. & $\mathrm{P}(\mathrm{NP})$ & Rubus canescens DC. & 1 & GOL147 / Forests \& shrubs & EUR \\
\hline 129. & $\mathrm{H}$ & Sanguisorba minor Scop. & 1 & GOL148 / Grasslands (N, E, S, W) & EUA \\
\hline 130. & $\mathrm{H}$ & Sanguisorba officinalis L. & 1 & GOL149 / Grasslands (N,E) & CSM \\
\hline 131. & $\mathrm{P}(\mathrm{NP})$ & Sorbus torminalis (L.) Crantz. & 1 & GOL $150 /$ Forests \& shrubs & EUR \\
\hline
\end{tabular}




\begin{tabular}{|c|c|c|c|c|c|}
\hline \multirow[b]{2}{*}{132.} & \multirow{3}{*}{$\mathrm{P}(\mathrm{NP})$} & \multicolumn{4}{|l|}{ Rhamnacaeae } \\
\hline & & Frangula alnus Mill. & 1 & GOL162 / Forests \& shrubs & EUA \\
\hline & & Ulmaceae & & & \\
\hline \multirow[t]{2}{*}{133.} & $P$ & $\begin{array}{l}\text { Ulmus glabra Huds. } \\
\text { [Ulmus campestris L.] }\end{array}$ & 1 & GOL221 / Forests \& shrubs & EUA \\
\hline & & Geraniaceae & & & \\
\hline 134. & $\mathrm{~T}$ & Erodium cicutarium (L.) L'Her. & 1 & GOL 128 / Grasslands (S, W) & EUA \\
\hline \multirow[t]{2}{*}{135.} & $\mathrm{H}$ & Geranium sanguineum L. & 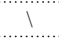 & GOL129 / Grasslands. Forest. (N, E, S, W) & EUR \\
\hline & & Fagaceae & & & \\
\hline 136. & P & Quercus cerris $\mathrm{L}$. & 1 & GOL 085 / Forests \& shrubs & EUR \\
\hline 137. & P & Quercus frainetto Ten. & 1 & GOL086 / Forests \& shrubs & EUR \\
\hline \multirow[t]{2}{*}{138.} & P & Quercus pubescens Willd. & !! & GOL087 / Forests \& shrubs & SMD \\
\hline & & Corylaceae & & & \\
\hline 139. & $\mathrm{P}$ & Carpinus betulus L. & 1 & GOL198 / Forests \& shrubs & EUA \\
\hline 140. & $\mathrm{P}(\mathrm{NP})$ & Carpinus orientalis Mill. & 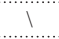 & GOL199 / Forests \& shrubs & EUA \\
\hline \multirow[t]{2}{*}{ 141. } & $\mathrm{P}(\mathrm{NP})$ & Corylus avellana $\mathrm{L}$ & ! & GOL200 / Forests \& shrubs & EUR \\
\hline & & Lythraceae & & & \\
\hline \multirow[t]{2}{*}{ 142. } & $\mathrm{H}$ & Lythrum salicaria L. & 1 & GOL120 / Grasslands (N, E) & CSM \\
\hline & & Anacardiaceae & & & \\
\hline \multirow[t]{2}{*}{ 143. } & P & Cotinus coggygria Scop. & 1 & GOL004 / Forests \& shrubs & EUA \\
\hline & & Sapindaceae & & & \\
\hline 144. & P & Acer campestre $\mathrm{L}$. & 1 & GOL121 / Forests \& shrubs & PNT \\
\hline 145. & $\mathrm{P}$ & Acer monspessulanum L. & 1 & GOL 122 / Forests \& shrubs & EUR \\
\hline 146. & $\mathrm{P}$ & Acer obtusatum Waldst. et Kit. ex Willd. & 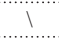 & GOL123 / Forests \& shrubs & BLK \\
\hline \multirow[t]{2}{*}{ 147. } & $\mathrm{P}$ & Acer tataricum L. & 1 & GOL124 / Forests \& shrubs & EUA \\
\hline & & Apiaceae & & & \\
\hline 148. & $\mathrm{~T}$ & Bupleurum flavicans Boiss. et Heldr. & 1 & GOL021 / Grasslands (N, E, S, W) & BLK \\
\hline 149. & $\mathrm{H}$ & Laserpitium siler $\mathrm{L}$. & 1 & GOL022 / Grasslands (N) & EUR \\
\hline 150. & $\mathrm{~T}$ & Orlaya grandiflora (L.) Hoffm & 1 & GOL023 / Grasslands (N, E, S) & MED \\
\hline 151. & $\mathrm{H}$ & Physospermum cornubiense (L.) DC. & 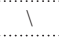 & GOL024 / Forests \& shrubs. & MED \\
\hline 152. & $\mathrm{H}$ & Smyrnium perfoliatum L. & 1 & GOL025 / Forests \& shrubs. & EUR \\
\hline \multirow[t]{2}{*}{153.} & $\mathrm{H}$ & Trinia glauca (L.) Dumort. & 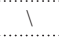 & GOL026 / Grasslands. (N, E, S, W) & MED \\
\hline & & Rutaceae & & & \\
\hline 154. & $\mathrm{Ch}$ & Dictamnus albus L. & 1 & GOL027 / Forests \& shrubs. & EUA \\
\hline \multirow[t]{2}{*}{155.} & $\mathrm{Ch}$ & Haplophyllum boisserianum Vis. et Panc. & $\begin{array}{l}\text { EN } \\
\text { End }\end{array}$ & GOL028 / Rocky grasslands. (W) & ILY \\
\hline & & Thymelaceae & & & \\
\hline 156. & $\mathrm{Ch}$ & Daphne cneorum L. & EN & GOL054 / Grassland. (N) & EUR \\
\hline \multirow[t]{2}{*}{157.} & $\mathrm{~T}$ & $\begin{array}{l}\text { Thymelaea passerina }(\mathrm{L} .) \text { Cosson \& } \\
\text { Germ. } \\
\text { [Lygia passerina }(\mathrm{L} .) \text { Fass.] }\end{array}$ & 1 & GOL055 / Grassland. (W) & EUR \\
\hline & & Cistaceae & & & \\
\hline 158. & $\mathrm{Ch}$ & Fumana bonaparteii Maire \& Petitm. & ! & GOL099 / Grassland (N, E, S, W) & BLK \\
\hline \multirow[t]{2}{*}{ 159. } & $\mathrm{Ch}$ & Helianthemum nummularium (L.) Mill. & 1 & GOL 100 / Grassland (N, E, S) & EUA \\
\hline & & Malvacea & & & \\
\hline \multirow[t]{2}{*}{160.} & $\mathrm{P}$ & Tilia platyphyllos Scop. & 1 & GOL034 / Forests \& shrubs. & EUR \\
\hline & & Brassicaceae & & & \\
\hline 161. & $\mathrm{T}$ & Aethionema saxatile L. R. Rr. & 1 & GOL040 / Grassland. (N, E, S, W) & SMD \\
\hline 162. & $\mathrm{H}$ & Alyssum markgrafi O.E. Schultz. & 1 & GOL041 / Forests \& shrubs & BLK \\
\hline 163. & $\mathrm{H}$ & Alyssum montanum L. & 1 & GOL042 / Grasslands. Forest. (N, E, S, W) & SMD \\
\hline 164. & $\mathrm{H}$ & Alyssum murale W. et K. & 1 & GOL043 / Grasslands. (N, E, S, W) & SMD \\
\hline 165. & $\mathrm{H}$ & Capsella bursa-pastoris (L.) Med. & 1 & GOL044 / Grasslands. Forest. (N, E, S, W) & CSM \\
\hline 166. & $\mathrm{H}$ & Erysimum sylvestre (Crantz.) Scop. & 1 & GOL045 / Grasslands. (N, E, W) & ALP \\
\hline 167. & $\mathrm{~T}$ & $\begin{array}{l}\text { Pseudoturritis turrita (L.) Al-Shehbaz } \\
{[\text { Arabis turrita L.]. }}\end{array}$ & 1 & GOL046 / Forests \& shrubs & SMD \\
\hline 168. & $\mathrm{H}$ & Rorippa lippizensis (Wulfen) Rchb. & 1 & GOL047 / Grasslands. (N, E, S, W) & ILY \\
\hline
\end{tabular}




\begin{tabular}{|c|c|c|c|c|c|}
\hline 169. & $\mathrm{~T}$ & $\begin{array}{l}\text { Microthlaspi perfoliatum (L.) F. K. Mey. } \\
\text { [Thllaspi perfoliatum L.] }\end{array}$ & 1 & GOL048 / Forest \& shrubs. & EUA \\
\hline \multirow[t]{2}{*}{ 170. } & $\mathrm{H}$ & Thlaspi praecox Wulfen & 1 & GOL049 / Grasslands. Rocky pastures. (N, S, W) & SMD \\
\hline & & Santalaceae & & & \\
\hline 171. & $\mathrm{Ch}$ & $\begin{array}{l}\text { Comandra umbellata subsp. elegans } \\
\text { (Spreng.) Piehl } \\
\text { [Comandra elegans (Roch.) Rchb.] }\end{array}$ & 1 & GOL019 / Grasslands (N, E, W) & BLK \\
\hline \multirow[t]{2}{*}{172.} & $\mathrm{H}$ & Thesium ramosum Hayne. & 1 & GOL020 / Grasslands. Forests. (N, E, W) & EUA \\
\hline & & Polygonaceae & & & \\
\hline \multirow[t]{2}{*}{173.} & $\mathrm{H}$ & Rumex acetosella L. & 1 & GOL039 / Grasslands (N, E, S, W) & CSM \\
\hline & & Plumbaginaceae & & & \\
\hline \multirow[t]{2}{*}{174.} & $\mathrm{H}$ & Goniolimon collinum (Griss.) Boiss. & 1 & GOL265 / Grasslands (W) & SMD \\
\hline & & Caryophyllaceae & & & \\
\hline 175. & $\mathrm{Ch}$ & Cerastium arvense L. subsp. ciliatum & 1 & GOL158 / Grasslands (N, E, S, W) & CRP \\
\hline 176. & $\mathrm{~T}$ & Cerastium pumilum Curtis & 1 & GOL159 / Grasslands (N, E, S, W) & EUR \\
\hline 177. & $\mathrm{H}$ & Dianthus carthusianorum L. & 1 & GOL160 / Grasslands (N, E, S, W) & SMD \\
\hline 178. & $\mathrm{~T}$ & Holosteum umbellatum L. & 1 & GOL161 / Grasslands (N) & EUA \\
\hline 179. & $\mathrm{H}$ & Minuartia verna (L.) Hiern & 1 & GOL162 / Grasslands (N, E, S, W) & CRP \\
\hline 180. & $\mathrm{H}$ & Paronychia kapela (Hacq.) Kerner & 1 & GOL163 / Grasslands (N, E, S, W) & EUR \\
\hline 181. & $\mathrm{H}$ & $\begin{array}{l}\text { Petrorhagia saxifraga (L.) Link. } \\
{[\text { Tunica saxifraga }(\text { L.) Scop.] }}\end{array}$ & 1 & GOL164 / Grasslands (N, E, S, W) & SMD \\
\hline 182. & $\mathrm{H}$ & Scleranthus annuus $\mathrm{L}$. & 1 & GOL165 / Grasslands (W) & EUA \\
\hline 183. & $\mathrm{H}$ & Silene italica (L.) Persl. & 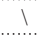 & GOL166 / Forests \& shrubs. & MED \\
\hline 184. & $\mathrm{H}$ & $\begin{array}{l}\text { Silene longiflora } \text { Ehrh. } \\
\text { [S. bupleuroides Chater et Walters] }\end{array}$ & 1 & GOL167 / Grasslands (N, E, W) & EUR \\
\hline 185. & $\mathrm{H}$ & Silene nutans $\mathrm{L}$. & 1 & GOL168 / Forests \& shrubs. & EUR \\
\hline 186. & $\mathrm{H}$ & Silene otites (L.) Wibel. & 1 & GOL169 / Grasslands (N, E, S, W) & EUR \\
\hline 187. & $\mathrm{H}$ & Silene paradoxa $\mathrm{L}$. & 1 & GOL170 / Grasslands (N, E, S, W) & EUR \\
\hline 188. & $\mathrm{H}$ & Silene viridiflora L. & 1 & GOL171 / Forests \& shrubs. & EUR \\
\hline 189. & $\mathrm{H}$ & Silene vulgaris (Moench.) Garcke & 1 & GOL172 / Grasslands (N, E, S, W) & EUA \\
\hline 190. & $\mathrm{H}$ & $\begin{array}{l}\text { Silene coronaria Claivr. } \\
{[\text { Lychnis coronaria }(\mathrm{L} .) \text { Desr.] }}\end{array}$ & 1 & GOL173 / Forests \& shrubs. & SMD \\
\hline 191. & $\mathrm{H}$ & $\begin{array}{l}\text { Silene viscaria (L.) Jess. } \\
{[\text { Lychnis viscaria }(\text { L.) K. Jess.] }}\end{array}$ & 1 & GOL174 / Forests \& shrubs. & CSM \\
\hline \multirow[t]{2}{*}{192.} & $\mathrm{H}$ & Stellaria holostea L. & 1 & GOL175 / Forests \& shrubs. Grasslands (N) & EUR \\
\hline & & Cornaceae & & & \\
\hline 193. & $\mathrm{P}(\mathrm{NP})$ & Cornus mas L. & 1 & GOL236 / Forests \& shrubs. & EUA \\
\hline \multirow[t]{2}{*}{194.} & $\mathrm{P}(\mathrm{NP})$ & Cornus sanguinea L. & 1 & GOL237 / Forests \& shrubs. & BLK \\
\hline & & Primulacea & & & \\
\hline 195. & G & Cyclamen hederifolium Aiton. & 1 & GOL176 / Forests \& shrubs. & SMD \\
\hline 196. & $\mathrm{H}$ & $\begin{array}{l}\text { Primula veris } \mathrm{L} . \\
\text { [Primmula officinalis }(\mathrm{L} .) \mathrm{Hill} .]\end{array}$ & 1 & GOL177 / Grasslands. (N, E, S) & EUR \\
\hline \multirow[t]{2}{*}{197.} & $\mathrm{H}$ & Primula vulgaris Huds. & 1 & GOL178 / Forests \& shrubs. & EUA \\
\hline & & Rubiaceae & & & \\
\hline 198. & $\mathrm{H}$ & Asperula cynanchica L. & 1 & GOL015 / Grasslands. (E, W) & SMD \\
\hline 199. & $\mathrm{G}$ & Asperula taurina $\mathrm{L}$ & 1 & GOL016 / Forests \& shrubs. & SMD \\
\hline 200. & $\mathrm{H}$ & Galium gerardi Will. & 1 & GOL017 / Grasslands. (N, E, S, W) & EUR \\
\hline \multirow[t]{2}{*}{201.} & $\mathrm{G}$ & Galium verum $\mathrm{L}$. & 1 & GOL018 / Grasslands. (N, E, S, W) & EUA \\
\hline & & Gentianaceae & & & \\
\hline 202. & $\mathrm{H}$ & Centaurium erythraea Rafn. & 1 & GOL238 / Grasslands. (N, E, S) & EUR \\
\hline \multirow[t]{2}{*}{203.} & $\mathrm{~T}$ & Centaurium pulchellum (Swartz.) Druce. & 1 & GOL239 / Grasslands. (S, W) & EUA \\
\hline & & Apocynaceae & & & \\
\hline 204. & $\mathrm{H}$ & Vincetoxicum huteri Vis. et Arch. & 1 & $\begin{array}{l}\text { GOL179 / Grasslands. Forests \& shrubs. (N, E, } \\
\text { S, W) }\end{array}$ & EUR \\
\hline
\end{tabular}




\begin{tabular}{|c|c|c|c|c|c|}
\hline & & Oleaceae & & & \\
\hline 205. & $\mathrm{H}$ & Forsythia europaea Degen \& Bald. & $\begin{array}{l}\text { LC } \\
\text { End }\end{array}$ & GOL001 / Forests \& shrubs. & BLK \\
\hline 206. & $\mathrm{P}(\mathrm{NP})$ & Fraxinus ornus L. & 1 & GOL002 / Forests \& shrubs. & ILY \\
\hline 207. & $\mathrm{P}(\mathrm{NP})$ & Ligustrum vulgare L. & 1 & GOL003 / Forests \& shrubs. & EUR \\
\hline & & Plantaginaceae & & & \\
\hline 208. & G & Digitalis lanata Ehrh. & 1 & GOL266 / Forests \& shrubs. & EUR \\
\hline 209. & $\mathrm{H}$ & Plantago argentea Chaix. & 1 & GOL267 / Grasslands. (N, E, W) & EUR \\
\hline 210. & $\mathrm{H}$ & Plantago lanceolata $\mathrm{L}$. & 1 & $\begin{array}{l}\text { GOL268 / Grasslands. Forest. Shrubs. (N, E, S, } \\
\text { W) }\end{array}$ & CSM \\
\hline 211. & $\mathrm{H}$ & Plantago media $\mathrm{L}$. & 1 & $\begin{array}{l}\text { GOL269 / Grasslands. Forest. Shrubs. (N, E, S, } \\
\text { W) }\end{array}$ & EUA \\
\hline 212. & $\mathrm{H}$ & Plantago subulata $\mathrm{L}$. & ! & GOL270 / Grasslands. (N, E, S, W) & EUA \\
\hline 213. & $\mathrm{H}$ & Veronica austriaca $\mathrm{L}$. & 1 & GOL271 / Grasslands. (E) & EUA \\
\hline 214. & $\mathrm{H}$ & Veronica chamaedrys $\mathrm{L}$. & 1 & GOL272 / Grasslands. Forests. (N, E, S) & EUA \\
\hline 215. & $\mathrm{H}$ & $\begin{array}{l}\text { Veronica austriaca subsp. jacquinii } \\
\text { (Baumg.) Eb. Fis. } \\
\text { [Veronica jacquinii Baumg.] }\end{array}$ & 1 & GOL273 / Grasslands. Forests. (N, E, S, W) & PNT \\
\hline 216. & $\mathrm{H}$ & Veronica spicata $\mathrm{L}$. & 1 & GOL274 / Grasslands. (N, E, S) & EUA \\
\hline 217. & $\mathrm{H}$ & Veronica officinalis L. & 1 & GOL275 / Forests \& shrubs. & CRP \\
\hline & & Scrophulariaceae & & & \\
\hline 218. & $\mathrm{~T}(\mathrm{H})$ & Verbascum phoeniceum L. & 1 & GOL101 / Grasslands. Forests. (N, E, S, W) & EUR \\
\hline & & Lamiaceae & & & \\
\hline 219. & $\mathrm{H}$ & Ajuga genevensis $\mathrm{L}$. & 1 & GOL201 / Forest \& shrubs. & EUA \\
\hline 220. & $\mathrm{G}$ & Ajuga laxmani (L.) Benth. & 1 & GOL202 / Forest \& shrubs. & EUR \\
\hline 221. & $\mathrm{H}$ & $\begin{array}{l}\text { Clinopodium grandiflorum }(\mathrm{L} .) \text { Kuntze } \\
{[\text { Calamintha grandiflora }(\mathrm{L} .)]}\end{array}$ & $\backslash$ & GOL203 / Forest \& shrubs. & SMD \\
\hline 222. & $\mathrm{H}$ & Clinopodium vulgare $\mathrm{L}$. & 1 & GOL204 / Forest \& shrubs. & EUA \\
\hline 223. & $\mathrm{~T}$ & Erophila verna (L.) Chevall. & 1 & GOL205 / Grasslands. (W) & BOR \\
\hline 224. & $\mathrm{H}$ & Origanum vulgare $\mathrm{L}$. & 1 & GOL206 / Forest \& shrubs. & EUR \\
\hline 225. & $\mathrm{H}$ & Prunella grandiflora $(\mathrm{L}$.) Scholler & 1 & GOL207 / Grasslands. (N) & EUR \\
\hline 226. & $\mathrm{H}$ & Prunella laciniata $\mathrm{L}$. & 1 & GOL208 / Grasslands. (N, E, W) & MED \\
\hline 227. & $\mathrm{Ch}$ & Satureja montana L. & 1 & GOL209 / Grasslands. (S,W) & MED \\
\hline 228. & $\mathrm{~T}$ & Sideritis montana L. & 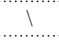 & GOL210 / Forest \& shrubs. & EUA \\
\hline 229. & $\mathrm{H}$ & Stachys officinalis (L.) Trev. & 1 & GOL211 / Grasslands. (N, E, W) & EUR \\
\hline 230. & $\mathrm{H}$ & Stachys scardica (Griseb.) Hayek. & 1 & GOL212/ Grasslands. Forest. (N, E, S, W) & BLK \\
\hline 231. & $\mathrm{H}$ & Stachys recta L. & 1 & GOL213 / Grasslands. (N, E, S, W) & PNT \\
\hline 232. & $\mathrm{Ch}$ & Teucrium chamaedrys $\mathrm{L}$. & 1 & GOL214 / Grasslands. Forests. (N, E, S, W) & MED \\
\hline 233. & $\mathrm{H}$ & Teucrium montanum L. & 1 & GOL215 / Grasslands. (N, E, S, W) & EUR \\
\hline 234. & $\mathrm{Ch}$ & Thymus longicaulis C. Pers. & 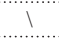 & GOL227 / Grasslands. (N, E, S, W) & BLK \\
\hline & & Orobanchaceae & & & \\
\hline 235. & $\mathrm{~T}$ & Euphrasia pectinata Ten. & 1 & GOL074 / Grasslands (N, S) & MED \\
\hline 236. & $\mathrm{~T}$ & Melampyrum cristatum L. & 1 & GOL075 / Grasslands (N) & EUR \\
\hline 237. & $\mathrm{~T}$ & Odontites luteus (L.) Clairv. & 1 & GOL076 / Grasslands. (N, E, W) & PNT \\
\hline 238. & $\operatorname{Par}(\mathrm{T})$ & Orobanche alba Stephen ex. Willd. & 1 & GOL077 / Grasslands. (E, W) & EUA \\
\hline 239. & $\operatorname{Par}(\mathrm{T})$ & $\begin{array}{l}\text { Orobanche gracilis } \mathrm{Sm} . \\
{[\text { O. cruenta } \text { Bertol.] }}\end{array}$ & 1 & GOL078 / Grasslands. (N, E, S, W) & MED \\
\hline 240. & $\mathrm{~T}$ & Parentucellia latifolia (L.) Caruel. & 1 & GOL079 / Grasslands. (E, W) & MED \\
\hline 241. & $\mathrm{T}$ & Rhinanthus rumelicus Vel. & 1 & GOL080 / Grasslands. (N, W) & BLK \\
\hline & & Convolvulaceae & & & \\
\hline 242. & $\mathrm{G}$ & Calystegia sepium $\mathrm{R}$. Br. & 1 & GOL058 / Forests. & CSM \\
\hline 243. & $\mathrm{H}$ & Convolvulus cantabricus $\mathrm{L}$. & 1 & $\begin{array}{l}\text { GOL059 / Forests \& shrubs. Grasslands. (N, E, } \\
\text { S, W) }\end{array}$ & SMD \\
\hline 244. & $\operatorname{Par}(\mathrm{T})$ & Cuscuta europaea $\mathrm{L}$. & 1 & GOL060 / Grasslands. (N, E, W) & CSM \\
\hline & & Boraginaceae & & & \\
\hline 245. & $\mathrm{~T}$ & Buglosoides arvensis (L.) I. M. & 1 & GOL112 / Grasslands. (N, S, W) & EUA \\
\hline
\end{tabular}




\begin{tabular}{|c|c|c|c|c|c|}
\hline 246. & $\mathrm{H}$ & Echium rubrum Forssk. & 1 & GOL113 / Grasslands. (N, E, S, W) & PNT \\
\hline 247. & $\mathrm{H}$ & Halacsya sendtneri (Boiss.) Doerfl. & $\begin{array}{l}\text { LC } \\
\text { End }\end{array}$ & GOL114 / Grasslands. (N, E, S, W) & BLK \\
\hline 248. & $\mathrm{Ch}$ & Lithospermum purpuro-coeruleum L. & 1 & GOL115 / Forests \& shrubs. & PNT \\
\hline 249. & $\mathrm{H}$ & Myosotis sylvatica Hoffm. & 1 & GOL116 / Forests \& shrubs. & EUA \\
\hline 250. & $\mathrm{Ch}$ & $\begin{array}{l}\text { Paramoltkia doerfleri (Wettst.) Gre. \& } \\
\text { Burd. } \\
\text { [Moltkia doerfleri Wettst.] }\end{array}$ & $\begin{array}{l}\text { NT } \\
\text { End }\end{array}$ & GOL117 / Forests \& shrubs. & BLK \\
\hline \multirow[t]{2}{*}{251.} & G & Symphytum tuberosum L. & 1 & GOL118 / Forests \& shrubs. & PNT \\
\hline & & Araliaceae & & & \\
\hline \multirow[t]{2}{*}{252.} & P & Hedera helix $\mathrm{L}$. & 1 & GOL089 / Forests \& shrubs. & SMD . \\
\hline & & Adoxaceae & & & \\
\hline \multirow[t]{2}{*}{253.} & $\mathrm{P}(\mathrm{NP})$ & Viburnum lantana $\mathrm{L}$. & 1 & GOL035 / Forests \& shrubs. & EUR \\
\hline & & Caprifoliaceae & & & \\
\hline \multirow[t]{2}{*}{254.} & $\mathrm{P}(\mathrm{NP})$ & Lonicera caprifolium L. & 1 & GOL090 / Forests \& shrubs. & EUR \\
\hline & & Dipsacaceae & & & \\
\hline \multirow[t]{2}{*}{255.} & $\mathrm{H}$ & Knautia drymeia Heuff. & 1 & GOL091 / Forests \& shrubs. Grasslands. (N) & BLK \\
\hline & & Valerianaceae & & & \\
\hline \multirow[t]{2}{*}{256.} & $\mathrm{~T}$ & $\begin{array}{l}\text { Valerianella dentata (L.) Pollich. } \\
\text { [V. morisonii (Sprengel) D. C.]. }\end{array}$ & 1 & GOL036 / Grasslands (E) & SMD \\
\hline & & Campanulaceae & & & \\
\hline 257. & $\mathrm{H}$ & $\begin{array}{l}\text { Asyneuma limonifolium }(\mathrm{L} .) \text { Janchen } \\
\text { [ A.parviflorum Turrill] }\end{array}$ & 1 & GOL093 / Grasslands. (N, E, S, W) & MED \\
\hline 258. & $\mathrm{H}$ & Campanula glomerata $\mathrm{L}$. & 1 & GOL094 / Grasslands. (N, E, S, W) & EUA \\
\hline 259. & $\mathrm{H}$ & Campanula persicifolia $\mathrm{L}$. & 1 & GOL095 / Forests \& shrubs. & EUA \\
\hline 260. & $\mathrm{H}$ & Campanula rapunculus Panc. & 1 & GOL096 / Forests \& shrubs. & EUA \\
\hline \multirow[t]{2}{*}{261.} & $\mathrm{H}$ & Campanula trachelium $\mathrm{L}$. & 1 & GOL097 / Forests \& shrubs. & EUA \\
\hline & & Asteraceae & & & \\
\hline 262. & $\mathrm{H}$ & Achillea millefolium $\mathrm{L}$. & 1 & GOL277 / Grasslands. (N, E, S, W) & EUA \\
\hline 263. & $\mathrm{H}$ & $\begin{array}{l}\text { Anthemis cretica } \mathrm{L} \text {. } \\
\text { [A. montana } \mathrm{L} .]\end{array}$ & 1 & GOL278 / Grasslands. (N, E, S, W) & EUR \\
\hline 264. & $\mathrm{Ch}$ & $\begin{array}{l}\text { Artemisia alba Turra } \\
\text { [A. camphorata Vill.] }\end{array}$ & 1 & GOL279 / Grasslands. (N, E, S, W) & MED \\
\hline \multirow[t]{2}{*}{265.} & $\mathrm{H}$ & Bellis perennis $\mathrm{L}$. & 1 & GOL280 / Grasslands. (N, E, S) & EUR \\
\hline & $\mathrm{H}$ & Carduus acanthoides L. & 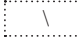 & GOL281 / Grasslands. (E) & EUR \\
\hline 266. & $\mathrm{H}$ & $\begin{array}{l}\text { Carduus micropterus (Borbas) Teyber } \\
\text { [C. nutans subsp. micropterus (Borbas) } \\
\text { Hayek] }\end{array}$ & 1 & GOL282 / Grasslands. (W) & EUA \\
\hline 267. & $\mathrm{H}$ & Centaurea albertii Rexhepi & $\begin{array}{l}\text { VU } \\
\text { End }\end{array}$ & GOL283 / Grasslands. (N, E, S, W) & BLK \\
\hline 268. & $\mathrm{H}$ & Centaurea jacea $\mathrm{L}$. & 1 & GOL284 / Grasslands. (N, E, S) & EUA \\
\hline 269. & $\mathrm{H}$ & $\begin{array}{l}\text { Centaurea stoebe subsp. australis (A. } \\
\text { Kern.) Greuter } \\
\text { [Centaurea stoebe L. subsp. micranthos } \\
\text { (Gmel.) Hayek]. }\end{array}$ & 1 & GOL285 / Grasslands. (N, E, S, W) & EUA \\
\hline 270. & $\mathrm{H}$ & Centaurea triumfetti All. & 1 & GOL286 / Grasslands. Forests. (N, E). & EUR \\
\hline 271. & $\mathrm{H}$ & $\begin{array}{l}\text { Cota tinctoria }(\mathrm{L} .) \text { J. Gay } \\
{[\text { A. tinctoria } \mathrm{L} .]}\end{array}$ & 1 & GOL287 / Grasslands (N, E, S, W) & EUA \\
\hline 272. & $\mathrm{H}$ & Cichorium intybus L. & 1 & GOL288 / Grasslands (N, E, S, W) & CSM \\
\hline 273. & $\mathrm{~T}$ & Crupina vulgaris Cass. & 1 & GOL289 / Grasslands (N, E, S, W) & PNT \\
\hline 274. & $\mathrm{~T}$ & Filago pyramidata $\mathrm{L}$. & 1 & GOL290 / Grasslands (N, E, S, W) & SMD \\
\hline 275. & $\mathrm{H}$ & $\begin{array}{l}\text { Galatella albanica Degen } \\
\text { [Aster albanicus subsp. albanicus] }\end{array}$ & $\begin{array}{l}\text { VU } \\
\text { End }\end{array}$ & GOL291 / Grasslands (E) & BLK \\
\hline 276. & $\mathrm{H}$ & $\begin{array}{l}\text { Galatella linosyris }(\mathrm{L} .) \text { Rchb. f. } \\
{[\text { Aster linosyris }(\mathrm{L} .) \text { Bernh] }}\end{array}$ & 1 & GOL292 / Grasslands. (N, E) & PNT \\
\hline 277. & G & Inula ensifolia L. & 1 & GOL293 / Grasslands. Forests. (N, E, W) & PNT \\
\hline 278. & $\mathrm{H}$ & Inula hirta $\mathrm{L}$. & 1 & GOL294 / Grasslands. (N, E, S, W) & EUA \\
\hline
\end{tabular}




\begin{tabular}{|c|c|c|c|c|c|}
\hline 279. & G & Inula salicina $\mathrm{L}$. & 1 & GOL295 / Grasslands. Forests. (N) & PNT \\
\hline 280. & $\mathrm{H}$ & $\begin{array}{l}\text { Jacobaea vulgaris Gaertn. } \\
\text { [Senecio jacobaea L.] }\end{array}$ & 1 & GOL102 / Grasslands (N, E, S, W) & EUA \\
\hline 281. & $\mathrm{H}$ & Jurinea mollis (L.) Reich. & 1 & GOL103 / Grasslands (N, E, S, W) & PNT \\
\hline 282. & $\mathrm{H}$ & $\begin{array}{l}\text { Klasea radiata (Waldst. \& Kit.) Á. Lö. } \\
\text { \& D. Lö. } \\
{[\text { Serratula radiata }(\text { W. et K.) Bieb.] }}\end{array}$ & CR & GOL104 / Grasslands. Forests. (N, E, W) & PNT \\
\hline 283. & $\mathrm{H}$ & Leontodon crispus Vill. & 1 & GOL105 / Grasslands (N, E, S, W) & BLK \\
\hline 284. & $\mathrm{H}$ & Leucanthemum vulgare (Lam.) DC. & 1 & GOL106 / Forests \& shrubs. & EUA \\
\hline 285. & $\mathrm{H}$ & $\begin{array}{l}\text { Pilosella piloselloides (Vill.) Soják } \\
\text { [Hieracium piloselloides Zahn] }\end{array}$ & 1 & GOL108 / Grasslands (N, E, S, W) & EUA \\
\hline 286. & $\mathrm{H}$ & $\begin{array}{l}\text { Pilosella piloselloides subsp. praealta } \\
\text { (Gochnat) S. Bräut. \& Greuter } \\
\text { [Hieracium praealtum Vill. (H. bauhinii } \\
\text { Besser).] }\end{array}$ & 1 & GOL109 / Grasslands (W) & EUA \\
\hline 287. & $\mathrm{~T}$ & Podospermum laciniatum (L.) DC. & … & GOL110 / Grasslands (N) & EUA \\
\hline 288. & $\mathrm{~T}$ & $\begin{array}{l}\text { Senecio leucanthemifolius subsp. vernalis } \\
\text { (Waldst. \& Kit.) Greuter } \\
\text { [Senecio vernalis W. et. K.] }\end{array}$ & $\backslash$ & GOL037 / Grasslands (N, W) & PNT \\
\hline 289. & $\mathrm{H}$ & Scorzonera austriaca Willd. & ! & GOL038 / Grasslands (N, E, S, W) & PNT \\
\hline 290. & $\mathrm{H}$ & Scorzonera hispanica L. & $\backslash$ & GOL151 / Grasslands (N, E, S) & PNT \\
\hline 291. & $\mathrm{H}$ & Tanacetum corymbosum (L.) Schultz. Bip. & 1 & GOL152 / Grasslands. Forests. (N, E, W) & PNT \\
\hline 292. & $\mathrm{H}$ & Taraxacum officinale Weber & 1 & GOL153 / Grasslands (N, E, S, W) & EUA \\
\hline 293. & $\mathrm{~T}$ & Xerantheтит аппиит L. & 1 & GOL154 / Grasslands (N, S) & SMD \\
\hline 294. & $\mathrm{~T}$ & Xeranthemum cylindraceum Sibth. et Sm. & 1 & GOL155 / Grasslands (N, E, W) & PNT \\
\hline
\end{tabular}

Legend: F-Forest, G-Grassland, \-Not threatened, LC - Least Concern, E-Endangered, CR -Critically Endangered, VU - Vulnerable, End - Endemic, EUR - European, EUA - Euro-Asiatic, PNT - Pontic, BLK - Balkans, CSM - Cosmopolitan, MED - Mediterranean, SMD - Sub-Mediterranean, BOR - Boreal, CRP - Circumpolar, ILY - Illyric, ALP - Alpine, PAL - Paleotemperate, SMZ - Submesic.

*Ordering of the plant families follows the arrangement as in: Exkursionsflora von Deutschland, 12th Edition (JÄGer et al., 2013)

Appendix II. Notes on pictures.

\begin{tabular}{lll} 
No. & Taxa & Photograph credentials \\
1. & Narcissus poeticus subsp. radiiflorus (Salisb.) Baker & Krasniqi, E. / 22.05.2016 \\
2. & Centaurea albertii Rexhepi & Krasniqi, E. / 11.07.2015 \\
3. & Galatella albanica Degen & Krasniqi, E. / 06.07.2017 \\
4. & Klasea radiata (Waldst. \& Kit.) Á. Lö. \& D. Lö. & Krasniqi, E. / 20.06.2015 \\
5. & Halacsya sendtneri (Boiss.) Doerfl. & Krasniqi, E. / 15.05.2016 \\
6. & Paramoltkia doerfleri (Wettst.) Gre. \& Burd. & Berisha, N. / 24.07.2016 \\
7. & Linum flavum L. & Berisha, N. / 25.05.2017 \\
8. & Forsythia europaea Degen \& Bald. & Krasniqi, E. / 21.04.2015 \\
9. & Polygala doerfleri Hayek & Berisha, N. / 10.06.2015 \\
10. & Potentilla visianii Pančić & Krasniqi, E. / 12.06.2017 \\
11. & Haplophyllum boisserianum Vis. et Panč. & Krasniqi, E. / 15.05.2016 \\
12. & Daphne cneorum L. & Krasniqi, E. / 20.04.2017 \\
\hline
\end{tabular}

